\title{
A reassessment of the osteology of Mourasuchus amazonensis Price, 1964 with comments on the taxonomy of the species
}

\author{
Giovanne M. Cidade, Douglas Riff, Jonas P. de Souza-Filho, \\ and Annie Schmaltz Hsiou
}

\begin{abstract}
This study is a thorough assessment on the morphology and taxonomy of Mourasuchus amazonensis, a fossil crocodylian of the Caimaninae clade from the late Miocene Solimões Formation of Brazil. A thorough redescription of the holotype of the species (DGM 562-R, a nearly complete skull with an associated incomplete left mandible) is performed together with the redescription of the specimen UFAC-1424, a posterior portion of the skull with associated mandibular remains, and the description of the specimen LACM-160157, also a posterior portion of the cranium. As such, this paper brings the most comprehensive osteological study of $M$. amazonensis to be performed to date, enabling a thorough taxonomic reassessment of the species in question. This reassessment confirmed $M$. amazonensis as a valid species, with two autapomorphies and two other distinctive characters. UFAC-1424 and LACM-160157 are assigned as Mourasuchus cf. M. amazonensis, pending further studies on the taxonomy of the species in order to clarify whether these specimens belong to the same species as DGM 526-R. Additionally, implications of the morphology observed in $M$. amazonensis for the taxonomic status of other Mourasuchus species are also discussed, especially with respect to $M$. nativus, which is currently a junior synonym of $M$. arendsi.
\end{abstract}

Giovanne M. Cidade. Departamento de Biologia, Faculdade de Filosofia, Ciências e Letras de Ribeirão Preto, Universidade de São Paulo, Ribeirão Preto-SP, 14040-901, Brazil; giovannecidade@hotmail.com Douglas Riff. Instituto de Biologia, Universidade Federal de Uberlândia, Uberlândia-MG, 38400-902, Brazil; driff2@gmail.com

Jonas P. de Souza-Filho. Museu de Paleontologia, Universidade Federal do Acre, Rio Branco-AC, 69915900, Brazil; jpdesouzafilho@hotmail.com

Annie Schmaltz Hsiou. Departamento de Biologia, Faculdade de Filosofia, Ciências e Letras de Ribeirão Preto, Universidade de São Paulo, Ribeirão Preto-SP, 14040-901, Brazil; anniehsiou@ffclrp.usp.br

Keywords: Mourasuchus amazonensis; Mourasuchus; Caimaninae; Crocodylia; Miocene; osteology

Cidade, Giovanne M., Riff, Douglas, de Souza-Filho, Jonas P., and Schmaltz Hsiou, Annie. 2019. A reassessment of the osteology of Mourasuchus amazonensis Price, 1964 with comments on the taxonomy of the species. Palaeontologia Electronica 22.2.44A 1-23. https://doi.org/10.26879/893

palaeo-electronica.org/content/2019/2602-mourasuchus-amazonensis

Copyright: July 2019 Society of Vertebrate Paleontology.

This is an open access article distributed under the terms of the Creative Commons Attribution License, which permits unrestricted use, distribution, and reproduction in any medium, provided the original author and source are credited.

creativecommons.org/licenses/by/4.0/creativecommons.org/licenses/by-nc-sa/4.0/ 


\section{INTRODUCTION}

The fossil crocodyliform fauna of the Miocene of South America is well-known for its taxonomic diversity, morphological disparity, niche partitioning, and abundance of specimens (Rusconi, 1933; Patterson, 1936, 1943; Langston, 1965; Langston and Gasparini, 1997; Aguilera, 2004; Linares, 2004; Paolillo and Linares, 2007; Salas-Gismondi et al., 2007, 2015; Riff et al., 2010; Scheyer and Moreno-Bernal, 2010; Bona et al., 2013a; Bona and Barrios, 2015; Moreno-Bernal et al., 2016; Scheyer and Delfino, 2016; Souza et al., 2016; Cidade et al., 2019a). The taxonomic diversity includes sebecids, a clade of non-eusuchian crocodyliforms (Langston, 1965; Paolillo and Linares, 2007; Salas-Gismondi et al., 2007), and the eusuchian clades Gavialoidea (Gürich, 1912; Langston, 1965; Bocquentin and Buffetaut, 1981; Brochu and Rincón, 2004; Riff and Aguilera, 2008), Crocodyloidea (Langston, 1965; Souza-Filho, 1993) and Alligatoroidea. This last group is represented mostly by taxa belonging to the clade Caimaninae, which also represents the most diverse crocodyliform group of the Miocene of South America (Riff et al., 2010; Bona et al., 2013a; Cidade et al., 2019a).

One of the most distinctive representatives of the caimanine fauna of the Miocene of South America is Mourasuchus, which is characterized mainly by its long, broad, dorsoventrally flattened rostrum and long, slender mandibles with extremely short symphyses in which most of the teeth are small in size (see Price, 1964; Langston, 1965; Cidade et al., 2017). Whereas these cranial features, together with some vertebral characters (see Langston, 2008 and Tineo et al., 2014), have led some to consider Mourasuchus as a "straining" or "filter" feeder (Langston, 1965; Riff et al., 2010; Bona et al., 2013b), and others as a "gulp-feeder" (Cidade et al., 2017), a thorough assessment of the feeding habits of this taxon is still to be made (Bona et al., 2013b; Cidade et al., 2017).

Mourasuchus includes the species M. amazonensis from the late Miocene of Brazil (Price, 1964; Souza-Filho and Guilherme, 2011a), M. atopus from the middle Miocene of Colombia and Peru (Langston, 1965; Langston and Gasparini, 1997; Salas-Gismondi et al., 2015), M. arendsi from the late Miocene of Venezuela, Brazil, and Argentina (Bocquentin-Villanueva, 1984; Souza-
Filho and Guilherme, 2011b; Scheyer \& Delfino, 2016; Cidade et al., 2019b), and M. pattersoni from the late Miocene of Venezuela (Cidade et al., 2017). Aside from these, there are several records of specimens assigned to "Mourasuchus sp." from different deposits of the middle and of the late Miocene of South America (e.g., Salas-Gismondi et al., 2007; Scheyer et al., 2013; Tineo et al., 2014; Moreno-Bernal et al., 2016; Scheyer and Delfino, 2016; Souza et al., 2016). Another species, Mourasuchus nativus, was erected by Gasparini (1985), but was later considered to be a junior synonym of $M$. arendsi by Scheyer and Delfino (2016).

The current record of Mourasuchus amazonensis is mainly restricted to the holotype DGM-526$\mathrm{R}$, an almost complete skull with an incomplete left hemimandible (see Price, 1964). An isolated left jugal (UFAC-5269) has also been referred to the taxon (Souza-Filho and Guilherme, 2011a). Both specimens are thought to be from the late Miocene Solimões Formation of Brazil, with the holotype coming from the Juruá River and the referred specimen from the "Morro do Careca" locality, both in the Acre state of Brazil. However, there has been some doubt about the exact stratigraphic provenance and age of the holotype, which will be detailed below.

The holotype of Mourasuchus amazonensis was only briefly described by Price (1964) and as the species was the first of the genus to be described, the diagnosis offered in the original work was the same as of the genus. However, diagnoses for Mourasuchus species described later were only minimally differentiated from $M$. amazonensis (see Langston, 1966 and Bocquentin-Villanueva, 1984). Recently, Cidade et al. (2017) provided a more detailed comparison between the Mourasuchus species, from which it could be shown that $M$. amazonensis is a valid species distinct from other Mourasuchus with respect to two autapomorphies, in addition to other distinguishing features (see Emended Diagnosis below). A detailed reevaluation of the holotype, however, has never been performed.

Therefore, the first objective of this paper is to provide a thorough redescription of the holotype of Mourasuchus amazonensis. The second objective is to provide a morphological assessment of two specimens from the late Miocene Solimões Formation of Brazil that may be tentatively assigned 
(Mourasuchus cf. amazonensis) to this species. One, UFAC-1424, is comprised of a posterior portion of the skull and a fragment of the left dentary and was originally attributed to $M$. nativus upon its original, brief description by Bocquentin and Souza-Filho (1990). The other, LACM-160157, has not previously been described and comprises a posterior portion of the skull. The third objective addresses the bearing that our revised understanding of $M$. amazonensis has on ongoing taxonomic issues regarding Mourasuchus, especially regarding the taxonomic status of $M$. nativus.

\section{MATERIALS AND METHODS}

The three specimens examined in this paper (the holotype of Mourasuchus amazonensis, DGM 526- $R$, and the specimens assigned as Mourasuchus cf. M. amazonensis LACM-160157 and UFAC-1424) are stored and available at their respective institutions. The specimens were compared with other Mourasuchus specimens, in particular the holotypes of M. atopus (UCMP-38012), $M$. arendsi (CIAAP-1297) and M. pattersoni (MCNC-PAL-110-72V), as well as specimens assigned to $M$. arendsi (MLP 73-IV-15-8, holotype of $M$. nativus; UFAC-5716). The skulls of osteological specimens of living crocodylians (see Appendix 1 for a list) were also used for comparison. The anatomical nomenclature follows that of lordansky (1973), unless otherwise noted.

\section{Institutional Abbreviations}

AMNH, American Museum of Natural History, New York, NY, USA; CIAAP, Centro de Investigaciones Antropológicas, Arqueológicas y Paleontológicas, Universidad Nacional Experimental Francisco de Miranda, Coro, Venezuela; DGM, Divisão de Geologia e Paleontologia do Departamento Nacional de Produção Mineral, Rio de Janeiro, Brazil; LACM, Los Angeles County Museum of Natural History, Los Angeles, CA, USA; MACN, Museo Argentino de Ciéncias Naturales "Bernardino Rivadávia", Buenos Aires, Argenrina; MCT, Museu de Ciências da Terra, Rio de Janeiro, Brazil; MN, Museu Nacional, Rio de Janeiro, Brazil; UFAC, Universidade Federal do Acre, Rio Branco, Brazil.

\section{GEOLOGICAL SETTINGS}

The Solimões Formation is located within the Acre and Solimões basins (Caputo et al., 1971; Eiras et al., 1994). The sediments of the Solimões Formation are continental in origin and composed mainly of claystones, with calcareous concretions and calcite as well as gypsum veins, lying in horizontal to subhorizontal beds that can reach thicknesses of over $1000 \mathrm{~m}$ (Latrubesse et al., 2010). The depositional environment of the Solimões Formation is predominantly floodplain-lacustrine-paludal according to Latrubesse et al. (2010), with the Andes chain being considered the main source of the sediments (Latrubesse et al., 1997). Some workers assigned a late Miocene/Pliocene age to the Solimões Formation as a whole (e.g., Latrubesse, 1992; Latrubesse et al., 1997), but recent geological, palynological, and sedimentological data suggests a late Miocene age for the formation (Cozzuol, 2006; Latrubesse et al., 2010), equivalent to the Huayquerian ( 9-6.8 Ma) South American Land Mammal Age-SALMA (Fortier et al., 2014).

The holotype of Mourasuchus amazonensis (DGM-526-R) was collected from an outcrop in the left bank of the Juruá River, located approximately $4 \mathrm{~km}$ upstream from the mouth of the São João stream, which is a tributary stemming from the right bank of the Juruá River, in the municipality of Marechal Thaumaturgo, Acre state, Brazil (Price, 1964; Figure 1). This locality is identified as "Number 33" in the map of Simpson and Paula-Couto (1981, figure 32) and was initially interpreted as being Pliocene in age (Price, 1964), but later works considered $M$. amazonensis as coming from the late Miocene (Bocquentin and Souza-Filho, 1990; Riff et al., 2010) following the age reassignment of the Solimões Formation (see Latrubesse et al., 2010; Ribeiro et al., 2013).

The specimens UFAC-1424 and LACM160157 were both collected in the "Niteroi" locality of the Solimões Formation, which is located on the right bank of the Acre River, between the cities of Rio Branco and Senador Guiomard (S 1008'30.0", W 67048'46.3"- Bona et al., 2013a; UTM 19L 629983 E /8879539 S, datum WGS84 - Kerber et al., 2018; Figure 1). The Niteroi locality is comprised of moderately consolidated claystone layers, with sandstones and siltstones in smaller quantities, deposited in a low-energy environment (Campbell et al., 2006). More information about the geology of this locality can be found in Latrubesse (1992) and Negri (2004).

\section{SYSTEMATIC PALEONTOLOGY}

\author{
Order CROCODYLIA Gmelin, 1789 (sensu Benton \\ and Clark, 1988) \\ Superfamily ALLIGATOROIDEA Gray, 1844 \\ Family ALLIGATORIDAE Cuvier, 1807
}




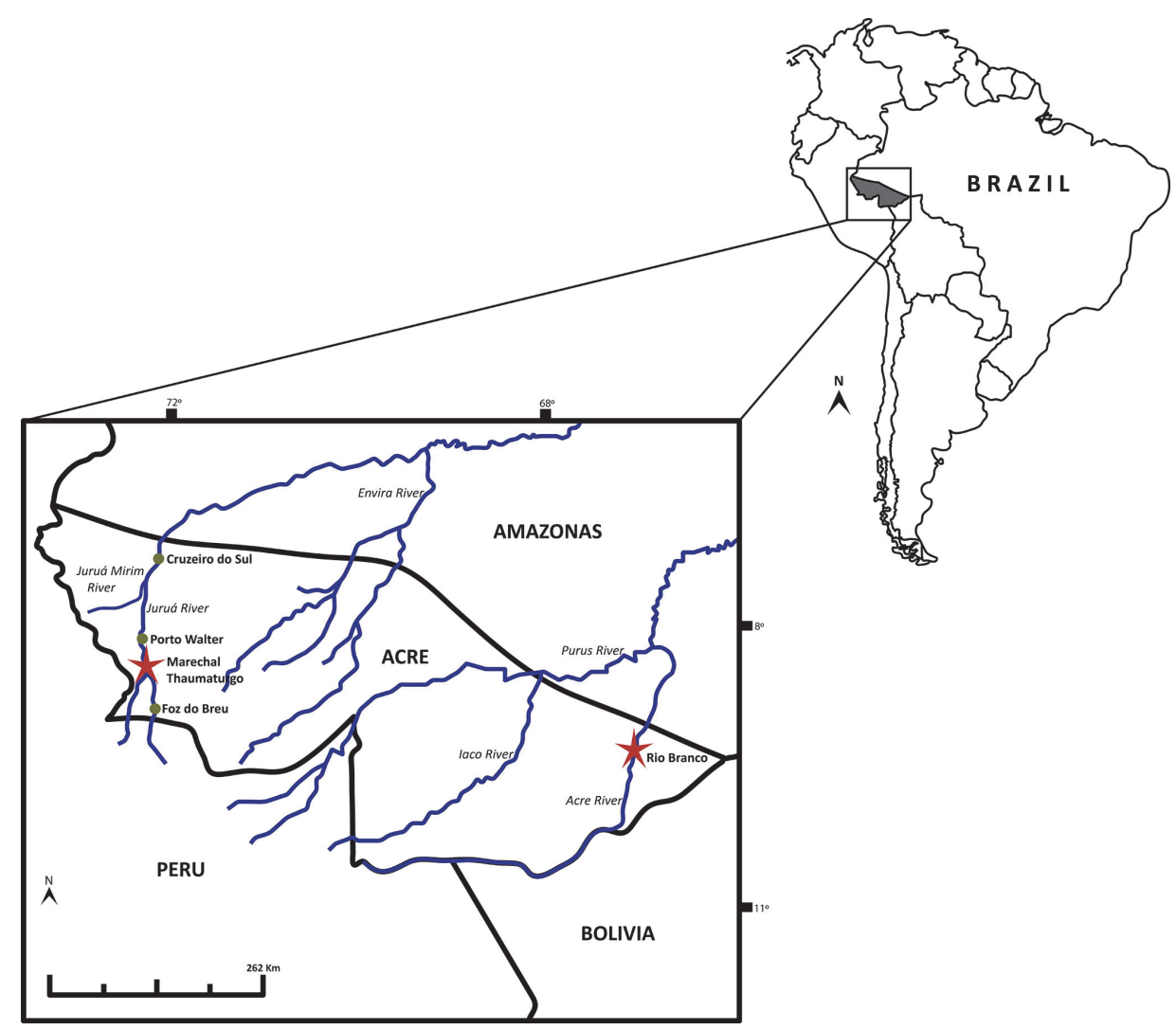

FIGURE 1. A map of the Brazilian state of Acre modified from Hsiou (2010) and Lopes (2016), with the red stars indicating the respective approximate localities in which were collected the holotype of M. amazonensis (near the city of Marechal Thaumaturgo) and the specimens UFAC-1424 and LACM-160157 (the Niteroi Site, near the city of Rio Branco).

\section{Subfamily CAIMANINAE Brochu, 1999 Genus Mourasuchus Price, 1964}

Type species. Mourasuchus amazonensis Price, 1964, by original designation.

Mourasuchus amazonensis Price, 1964

Holotype. DGM-526-R (nearly complete skull with associated left hemimandible).

Temporal range. Late Miocene.

Occurrences. DGM-526-R (holotype), from the left bank of the Juruá River, approximately $4 \mathrm{~km}$ upstream from the mouth of the São João stream, tributary of the Juruá River, municipality of Marechal Thaumaturgo (Price, 1964); UFAC-5269, an isolated left jugal from the 'Morro do Careca' locality, municipality of Feijó (Souza-Filho and Guilherme 2011a), Brazilian state of Acre, Solimões Formation (Figure 1).

Emended diagnosis. Jugal lateromedially expanded and dorsoventrally flattened (autapomorphy) and a tri-lobed incisive foramen (autapomorphy); differs from $M$. atopus and $M$. arendsi in having an external naris wider than long; differs from $M$. atopus and $M$. pattersoni in having lateromedially expanded palatines. Emended from Price (1964).

Description. Only the ventral view of the skull of the holotype could be directly assessed and described as the dorsal part of the skull is currently firmly attached to a plaster jacket (Figure 2). A removal of the jacket could not be done without risking serious damage to the holotype and was, therefore, not performed. The morphology of the skull in dorsal view can only be currently assessed through the drawing made by Price (1964, figure 1). The drawing generally matches the morphology of the other Mourasuchus species in both the general morphology of the skull as well as in most features deemed generally diagnostic of the genus, such as prefrontals meeting medially, the presence of accentuated bosses in the anteromedial margins of the orbits (synapomorphies of Mourasuchus; Cidade et al., 2017), and the large external naris (observed also in $M$. pattersoni but not in $M$. arendsi and $M$. atopus; Cidade et al., 2017). 

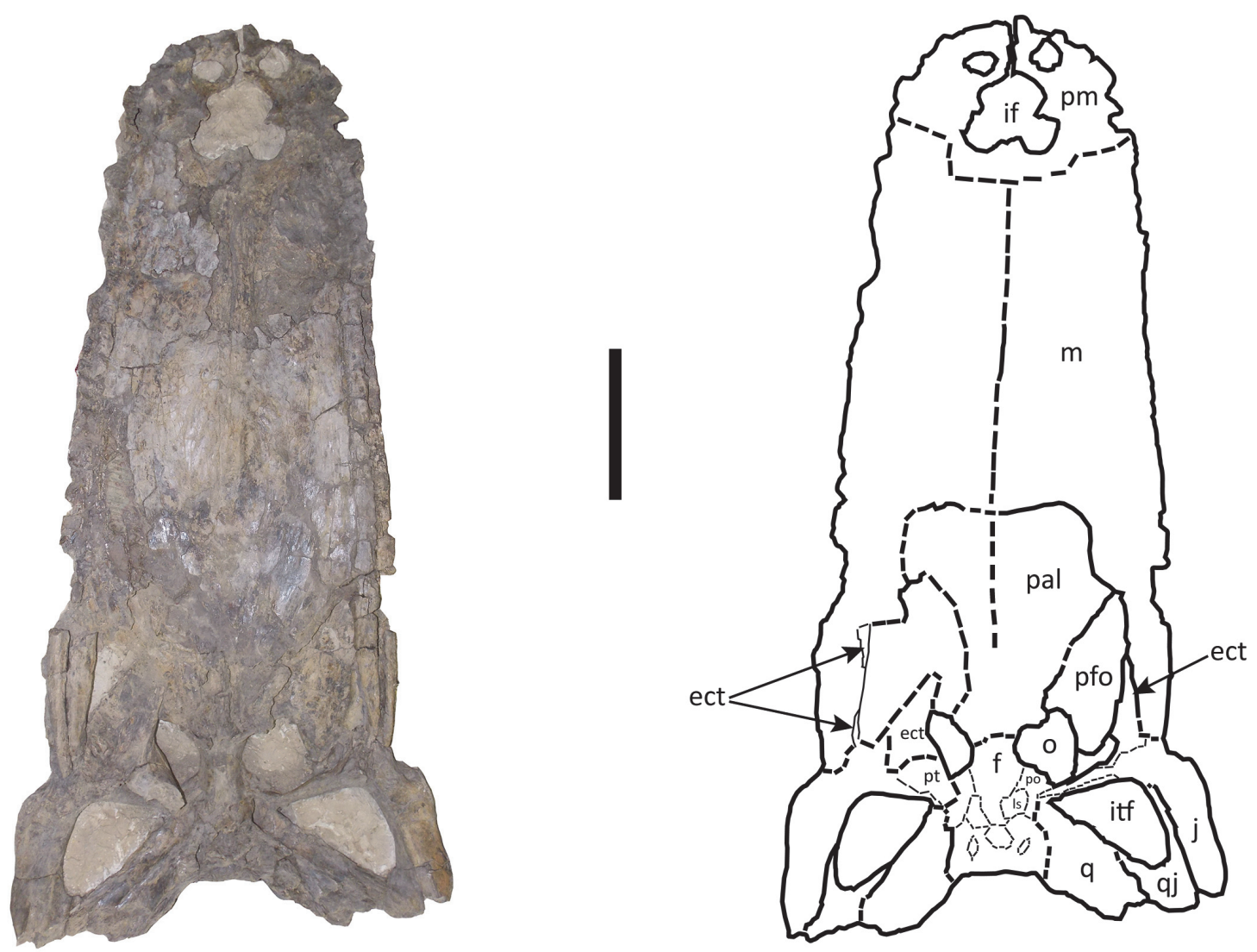

FIGURE 2. Skull of the holotype of Mourasuchus amazonensis (DGM 526-R) in ventral view with schematic drawing. Abbreviations: ect, ectopterygoid; f, frontal; if, incisive foramen; itf, infratemporal fenestra; j, jugal; m, maxilla; o, orbit; pal, palatine; pfo, palatine fossa; pm, premaxilla; po, postorbital; pt, pretygoid; q, quadrate; qj, quadatojugal. Scale equals $20 \mathrm{~cm}$.

In ventral view, the general preservation of the holotype is relatively poor, with many parts of the skull fragmented and several regions of bone surface eroded (Figures 2, 3, and 4). Nevertheless, the morphology of the bones observable in ventral view provides sufficient information for description.

Both premaxillae are present. The surfaces of both are severely eroded so that the sutures with the maxillae could not be confidently distinguished (Figures 2 and 3). In the left premaxillary tooth row, only the third alveolous is complete; the other four alveoli do not preserve their lateral margins. No alveolus is completely preserved in the right premaxillary tooth row, although wear surfaces can be seen in the areas that would correspond to the first, fourth, and fifth premaxillary alveoli. Despite the poor preservation of the premaxillae, it can be inferred that Mourasuchus amazonensis exhibited five premaxillary teeth, as seen in all caimanines except Paleosuchus (e.g., Brochu, 2011 and Cidade et al., 2017, Character 87, state 0). Three premaxillary occlusal fossae can be fully observed: those corresponding to both first dentary teeth (left and right) and, in the left premaxilla, that of the fourth dentary tooth (Figure 3 ). The latter demonstrates that the fourth dentary teeth occluded in a

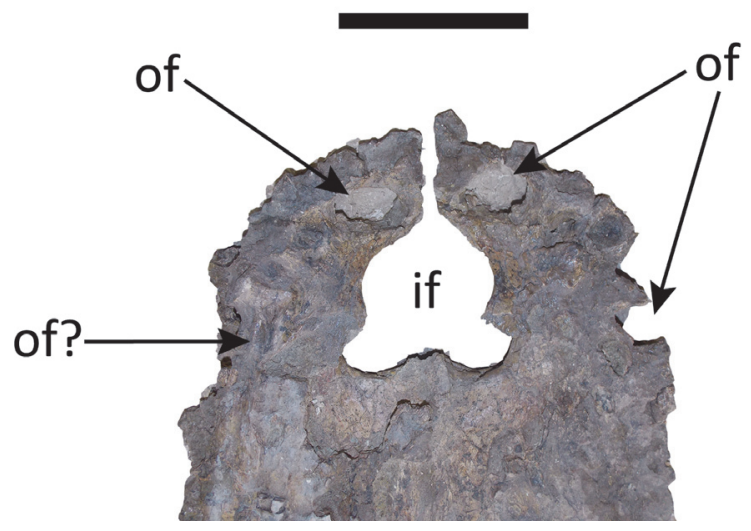

FIGURE 3. Premaxillae of the holotype of Mourasuchus amazonensis (DGM 526-R) in ventral view. Abbreviations: if, incisive foramen; of, occlusal fossa. Scale equals $10 \mathrm{~cm}$. 


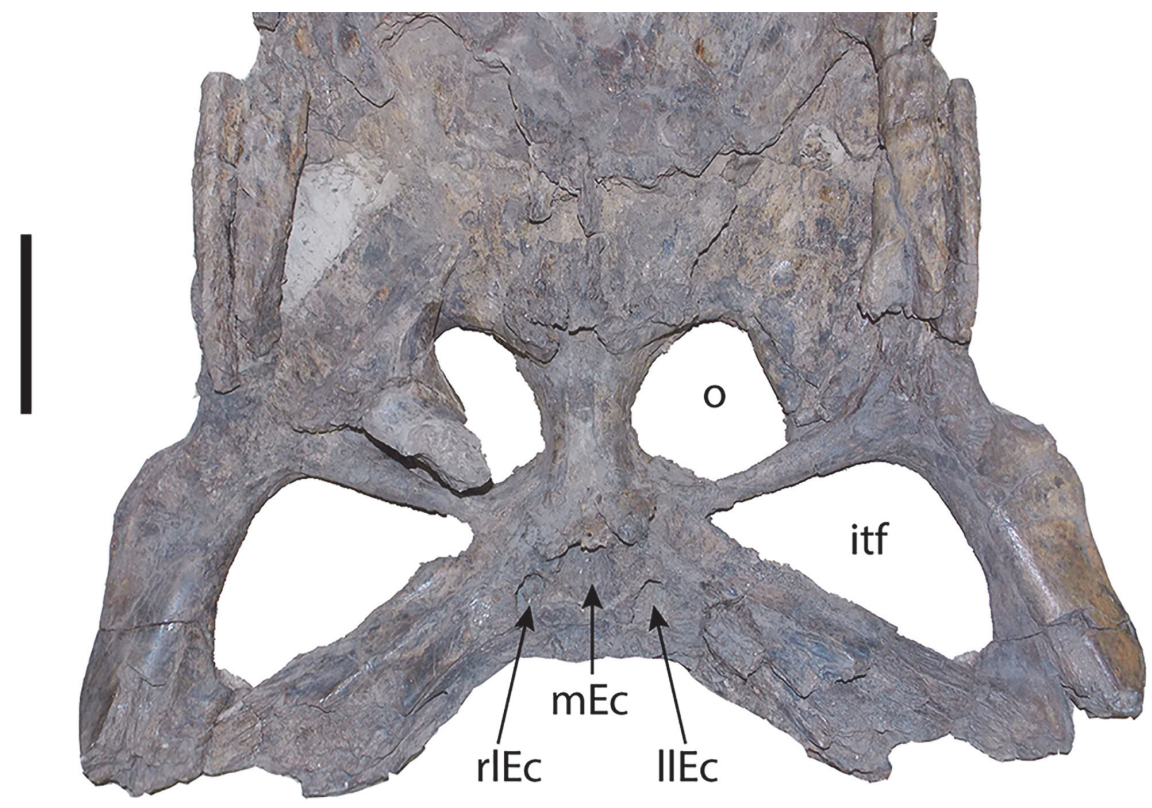

FIGURE 4. Posterior portion of the skull of the holotype of Mourasuchus amazonensis (DGM 526-R) in ventral view. Abbreviations: itf, infratemporal fenestra; IIEc, left lateral Eustachian canal; mEc, median Eustachian canal; o, orbit; rIEc, right lateral Eustachian canal.

pit rather than in a notch, as in all Alligatoroidea except Leidyosuchus canadensis (Brochu, 2011; Character 91, state 1). In the right premaxilla, a heavily eroded surface near the contact with the maxilla may correspond to the occlusal fossa for reception of the fourth dentary tooth, but this interpretation is only tentative due to the heavy erosion. The incisive foramen of $M$. amazonensis is large and tri-lobed in shape (Figures 2 and 3), distinguished from the small, circular foramen of M. pattersoni and from the large, "reversed teardropshaped" foramen described by Bocquentin-Villanueva (1984) for the holotype of $M$. arendsi, CIAAP1297 (see Cidade et al., 2017). The morphology of the incisive foramen in the holotype of $M$. arendsi, however, cannot be confirmed as the ventral portion of the skull of the specimen cannot be visualized as it is firmly attached to a wooden support (Cidade et al., 2018).

Both maxillae exhibit severe erosion throughout their ventral surfaces; this is most pronounced in the anterior portion of the left maxilla, whereas the areas of both tooth rows are also severely damaged (Figure 2). The overall morphology of the maxillae is congruent with that of all the other Mourasuchus specimens in being anteroposteriorly long, lateromedially wide, and dorsoventrally flattened (see Langston, 1965; Bocquentin-Villanueva, 1984; Cidade et al., 2017; Figure 2). The suture between the maxillae is only partially distinguishable (Figure 2). Posteriorly, the sutures con- necting the left maxilla with both the palatine and ectopterygoid are evident along most of their margins. The contact between the left maxilla and the jugal is discernible, even though the area between the bones in ventral view is eroded. Although the corresponding sutures of the right maxilla are discernible, only a small portion of the suture between the maxilla and the palatine, and limited points of contact between the maxilla and the ectopterygoid, are visible (Figure 2). According to Price (1964), each maxillae of the holotype of $M$. amazonensis had "more than 40 teeth", but only 14 partially preserved alveoli in the left maxilla and eight partially preserved alveoli in the right maxilla can be observed in the holotype in its current status. Nevertheless, given the size of the maxillae and the fact that the number of alveoli in all complete maxillae known for Mourasuchus exceed 40 (see Langston, 1965; Bocquentin-Villanueva, 1984), Price's statement is most likely correct. The posterior-most portions are the best preserved of both tooth rows. However, the limits between the alveoli are not preserved in either of these areas.

The palatines are incompletely preserved, comprising the medial and part of the dorsal margins of the suborbital fenestrae (Figure 2). The suture between the palatines is not evident. The anterior surface of the palatines is well preserved until approximately the mid-length of the medial margin of both suborbital fenestrae, after which the surface of both elements, especially the right one, 
is severely eroded. Due to this erosion, no contact with the pterygoid is preserved. The overall shape of the best-preserved areas of the palatines suggest they were lateromedially expanded in overall shape in Mourasuchus amazonensis, which would be similar to the morphology illustrated for $M$. arendsi by Bocquentin-Villanueva (1984) and to the specimens UFAC-1424 and LACM-160157 (Mourasuchus cf. amazonensis, see below), but different from that seen in $M$. atopus and $M$. pattersoni, which exhibit lateromedially constricted palatines. However, this can only be stated tentatively due to the incompleteness of the palatines in the holotype.

Both ectopterygoids are very incomplete. The left ectopterygoid is well preserved only in part of its anterior-most portion, which forms part of the lateral margin of the suborbital fenestra (Figure 2). The suture between this region of the left ectopterygoid and the maxilla is evident. Posterior to this, only the most internal portions of the left ectopterygoid are preserved, especially in the areas adjacent to the jugal, but the contact of the ectopterygoid with the jugal is not clear (Figure 2). The right ectopterygoid is more complete. However, two separate portions of the bone can be seen. One is in the lateral margin of the suborbital fenestra, contacting the right maxillae laterally (Figure 2), and the other, which comprises most of what is preserved of the bone, has been displaced, possibly during preparation, towards the medial portion of the skull in the posterior portion of the right suborbital fenestra (Figure 2). This displaced portion of the right ectopterygoid preserves the posterior part of the anterior process and the most lateral part of the pterygoid process of the ectopterygoid (sensu Brochu, 2011, Character 119).

The pterygoids are very damaged in all ventral surfaces. The only significant part of the ventral surface of the pterygoids that is preserved is the section of the right pterygoid that is attached to the displaced right ectopterygoid, contacting it dorsally (Figures 2 and 4). Most pterygoid parts observable in the holotype belong to the interior areas of the bone, including sections of the middle and both lateral Eustachian canals (Figures 2 and 4). The secondary choana cannot be observed.

Both postorbitals, both laterosphenoids, and the frontal can be seen in ventral view. However, all these bones are very fragmented (Figure 2) and little can be described. The ventral portions of the postorbital plates can be seen in both sides, whereas the dorsomedial portion of the descending process of the postorbital can be seen in the left
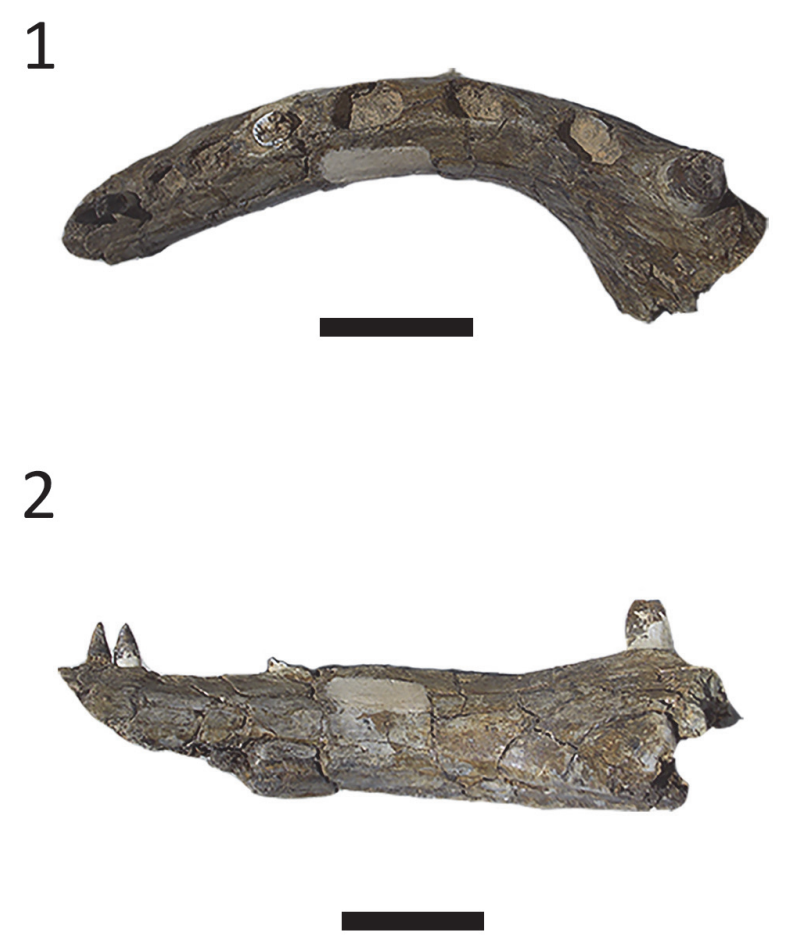

3

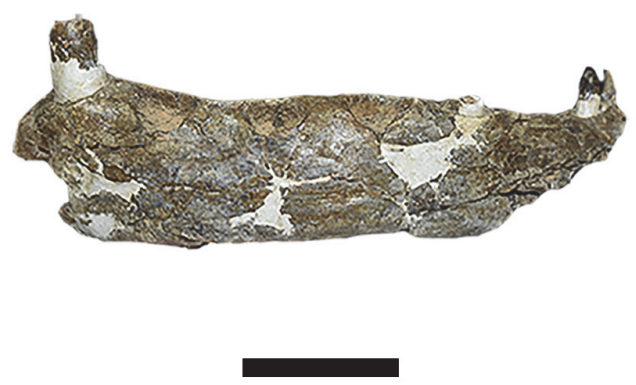

FIGURE 5. Anterior portion of the left mandibular ramus of the holotype of Mourasuchus amazonensis (DGM $526-R$ ) in dorsal (1), medial (2) and lateral (3) views. Scale equals $5 \mathrm{~cm}$.

bone (Figure 2). None of the detailed structures of the laterosphenoids, such as the trigeminal foramen, are clearly preserved. The ventral portion of the frontal can be seen (Figure 2), but the cristae cranii frontales, a pair of crests that surround the olfactory tract in extant crocodylians (lordansky, 1973), are severely damaged.

The jugals are nearly complete, except for eroded areas in the most posterior regions of both bones (Figure 2). The sutures with the quadratojugals are evident along their length, except for the extreme most posterior portion of the right suture 

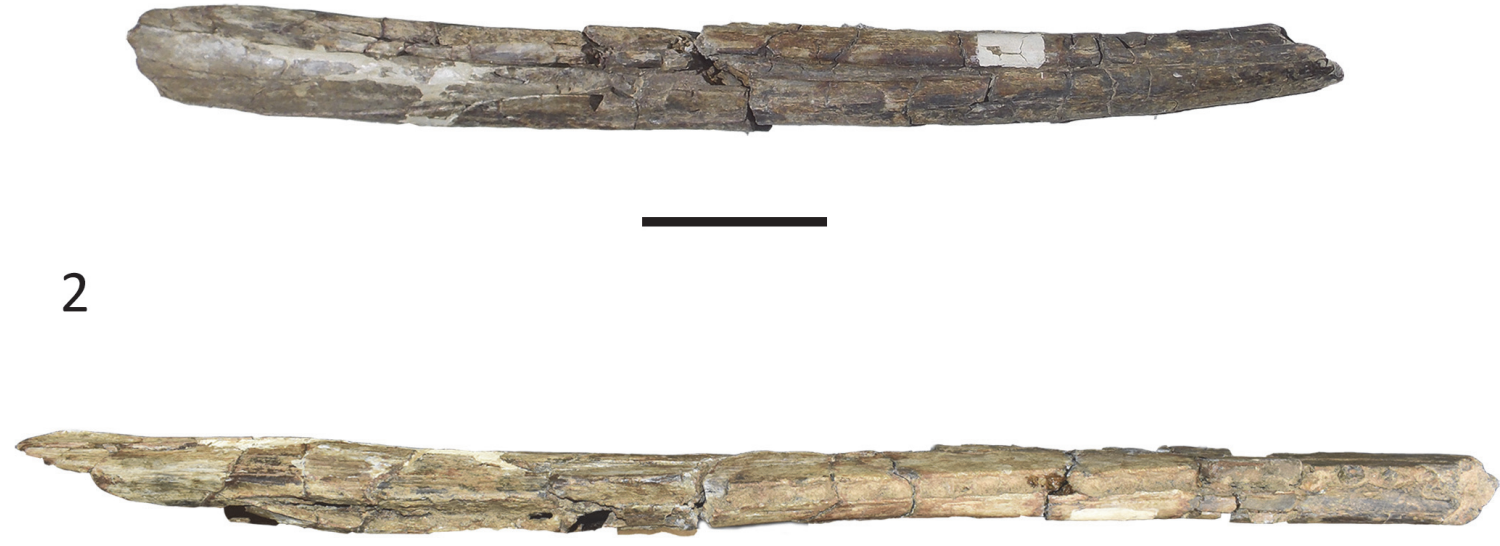

3

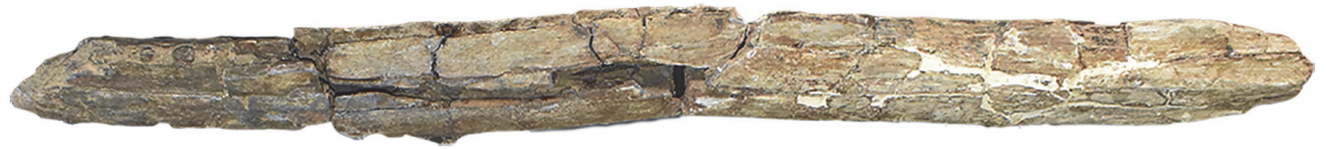

FIGURE 6. Posterior portion of the left mandibular ramus of the holotype of Mourasuchus amazonensis (DGM 526-R) in medial (1), dorsal (2) and lateral 93) views. Scale equals $10 \mathrm{~cm}$.

and the most anterior portion of the left suture. The ascending process of the jugal is preserved in both bones, forming the postorbital bar together with the descending processes of the postorbital. The subtemporal rami of the jugals, which are adjacent to the lateral margin of the infratemporal fenestrae, are lateromedially expanded and dorsoventrally flattened, distinct from the lateromedially slender, dorsoventrally flattened rami of $M$. atopus and $M$. arendsi, and from the both lateromedially and dorsoventrally expanded rami of $M$. pattersoni (see Cidade et al., 2017, fig. 8).

The posterior ends of both quadratojugals are eroded, whereas their ventral surfaces are also severely fragmented (Figures 2 and 4). The quadratojugals comprise the entire posterior angle of the infratemporal fenestrae, excluding the jugals (Figure 2), as it is common among alligatorid crocodylians (see Brochu, 1997). Both quadratojugals bear anterior processes in the lower temporal bar (Figure 2), a common morphology among noncrocodyloid crocodylians (Brochu, 1997, 2011).
Finally, the quadratojugals comprise at least half of the posteriomedial margin of the infratemporal fenestrae in ventral view. However, it is not possible to observe whether the quadratojugal reached the dorsal end of the posterior margin of the infratemporal fenestrae since this end cannot be visualized in the holotype in ventral view. The sutures with the quadrates are partially evident in both sides; only an anterior portion of the suture is evident in the right side, whereas most of the posterior portion is evident in the left side (Figure 2).

The quadrates are severely damaged along their posterior margins and ventral surfaces (Figures 2 and 4), and the quadrate condyles are not preserved. However, in both it is possible to observe the crest A' of lordansky (1973), which in Caiman latirostris is an insertion point of the $m$. adductor mandibular externus (Bona and Desojo, 2011). Despite the poor preservation of the pterygoids, the contact of these bones with the quadrates is mostly discernible (Figure 2), whereas the 
contact of the quadrates with the laterosphenoids is not evident.

The orbits of the holotype are circular, whereas the infratemporal fenestrae are roughly triangular in shape. The anteromedial extremity of the left infratemporal fenestra is pointed, whereas that of the right fenestra is rounded (Figures 2 and 4). This difference may be due to taphonomic distortion of the right fenestra. The infratemporal fenestrae are larger than the orbits, which is a unique feature of Mourasuchus among crocodylians (Bona et al., 2013a; Cidade et al., 2017).

Although Price (1964) mentioned the presence of "mandibulae", in the plural, only a nearly complete left dentary, with part of the anterior portion of the splenial, could be located at the collection (Figures 5 and 6). It preserves 33 alveoli, less than the "more than 40" teeth mentioned by Price (1964). However, as parts of the tooth row are not preserved, the number of more than 40 teeth is plausible and congruent with other descriptions of Mourasuchus (Langston, 1965; Bocquentin-Villanueva, 1984; Bocquentin and Souza-Filho, 1990; Cidade et al., 2017). Salas-Gismondi et al. (2015) stated that the first four alveoli are the largest in Mourasuchus, but in the holotype of $M$. amazonensis the fifth alveolus is also noticeably larger than the posterior ones (Figure 5.1), being closer to the first four alveoli in size. Six teeth are preserved in situ, although only two (in the eighth and ninth alveolous) are complete (Figure 7.3-7. 4), while the first tooth is almost complete (Figure 7.1-7.2). These teeth are conical, with unserrated carinae; the ninth tooth displays clear longitudinal striae, whereas the eighth has much of its enamel surface worn (Figure 7.3-7.4). The dentition of Mourasuchus is, thus, similar to that of most crocodylians (see Prasad and Broin, 2002; Souza et al., 2016). The mandibular symphysis does not extend beyond the first alveolus (Figure 5.1), a morphology that is unique to Mourasuchus among Crocodylia (Cidade et al., 2017). As most of the splenial is absent, the interior of the Meckelian canal of the dentary can be visualized in medial view (Figure 6.1). The anterior portion of the splenial is present but not well preserved, thus it cannot be stated whether the anterior end of the splenial was dorsal or ventral to the Meckelian groove (see Brochu, 1997, Character 50; Brochu, 2011, Character 54).

Mourasuchus cf. amazonensis Price, 1964

Temporal range. late Miocene

Occurrences. UFAC-1424 (posterior portion of the skull comprised by partial prefrontals, frontal, postorbital, parietal, squamosals, quadrates,
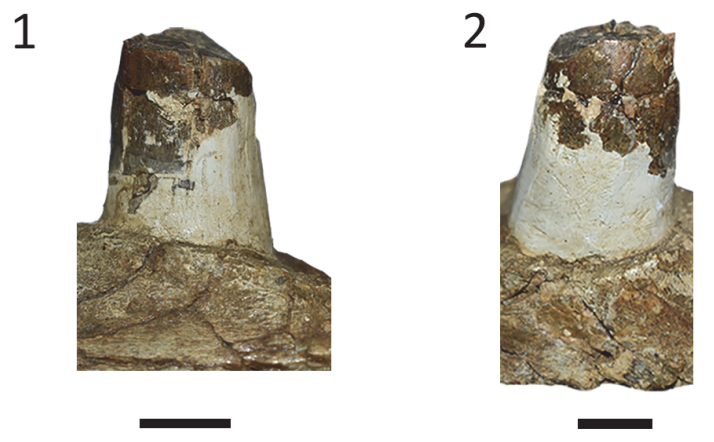

3

4
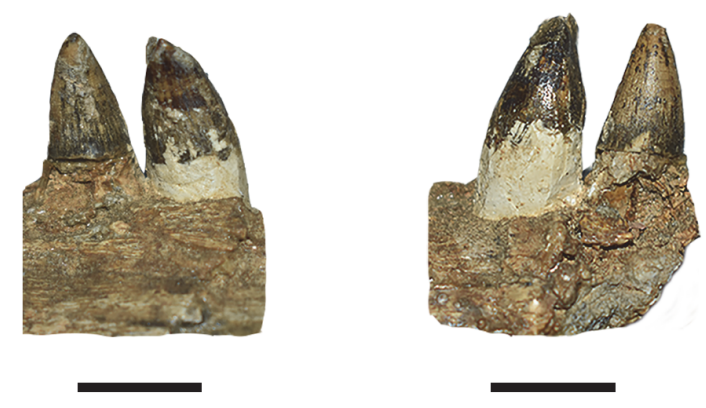

FIGURE 7. The most complete teeth of the anterior portion of the left mandibular ramus of the holotype of Mourasuchus amazonensis (DGM 526-R): the first tooth in lingual (1) and labial (2) views, and the eighth and ninth teeth in lingual (3) and labial (4) views. Scale equals $1 \mathrm{~cm}$.

quadratojugals, jugals, exoccipitals, pterygoids, ectopterygoids, partial lateosphenoids, partial palatines with associated left mandible comprised by partial dentary, partial surangular and partial angular; attributed to Mourasuchus nativus by Bocquentin and Souza-Filho, 1990; Figures 8, 9, 10, 11, 12 and 13) and LACM-160157 (posterior portion of the skull comprised by frontal, postorbital, parietal, squamosals, quadrates, quadratojugals, jugals, exoccipitals, basioccipital, pterygoids, ectopterygoids, laterosphenoids, palatines, and indeterminate fragments; Figures 14, 15, 16, 17, 18, 19, 20 , and 21). Both specimens are from the "Niteroi" locality, right bank of the Acre River, between the cities of Rio Branco and Senador Guiomard (S 1008'30.0", W 67048'46.3"- Bona et al., 2013a; UTM 19L 629983 E /8879539 S, datum WGS84 Kerber et al., 2018; Figure 1), Brazilian state of Acre, Solimões Formation.

Description. only UFAC-1424 preserves the prefrontals, albeit just their most posterior portions (Figure 8). The prefrontals meet medially, as in all Mourasuchus species and other Caimaninae taxa such as Purussaurus, Globidentosuchus brachyrostris, Caiman brevirostris, C. wannlangstoni, C. 

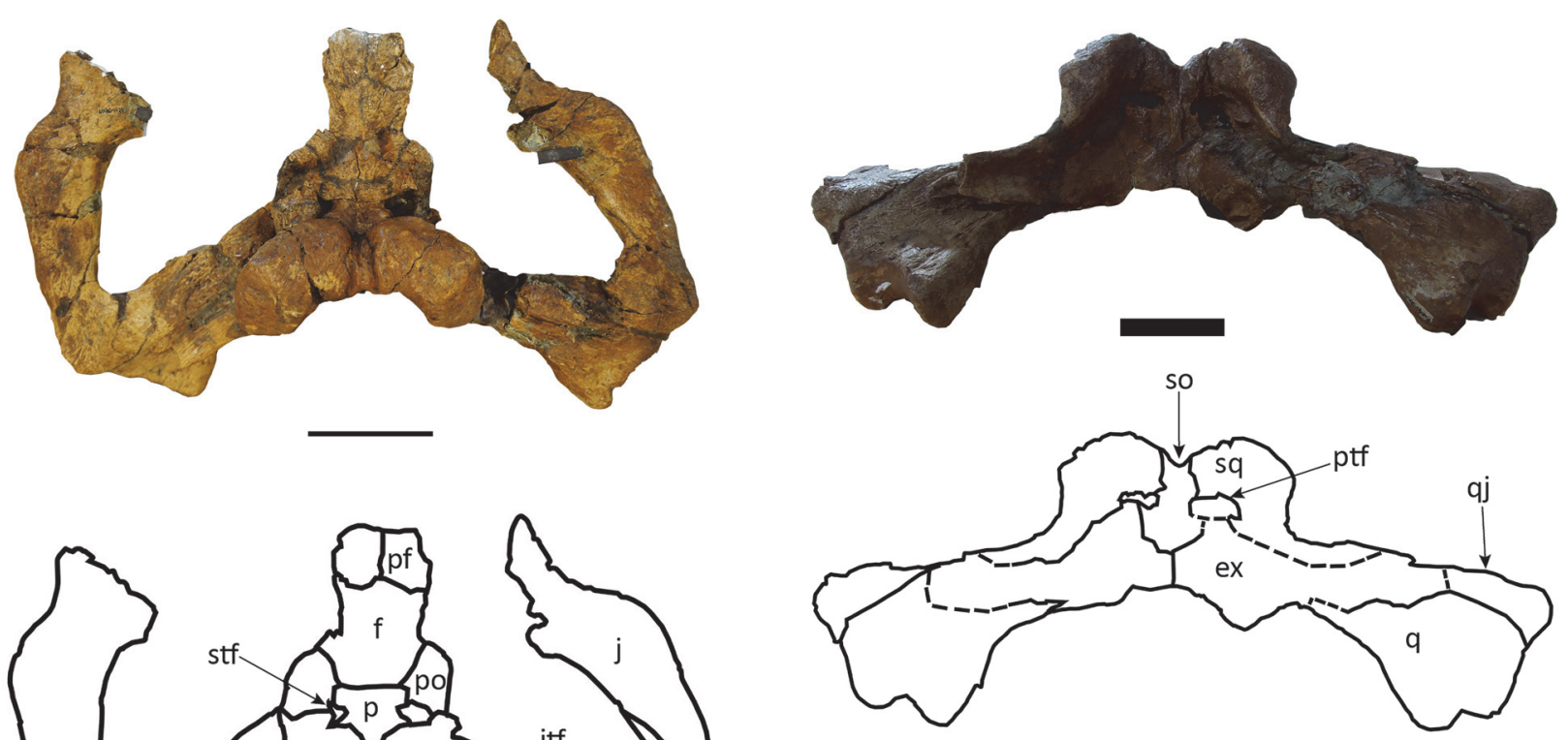

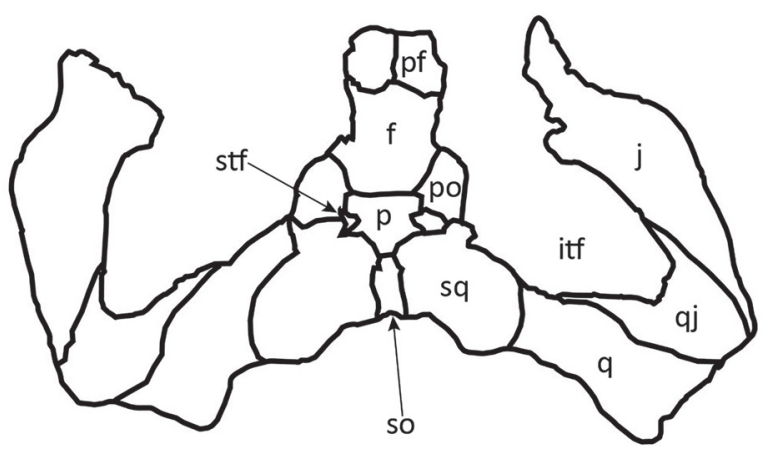

FIGURE 8. Skull of UFAC-1424 (Mourasuchus cf. M. amazonensis) in dorsal view with schematic drawing. Abbreviations: f, frontal; itf, infratemporal fenestra; $j$, jugal; p, parietal; pf, prefrontal; po, postorbital; q, quadrate; qj, quadatojugal; so, supraoccipital; sq, squamosal; stf, supratemporal fenestra. Scale equals $10 \mathrm{~cm}$.

yacare, and some individuals of $C$. crocodilus, $C$. latirostris and Melanosuchus niger (see Brochu, 2011, 2013; Scheyer et al., 2013; Bona et al., 2017; Cidade et al., 2017; Fernández-Blanco et al., 2018; Souza-Filho et al., 2019). The lateral-most portions of the postorbitals are absent, including the area around the orbits that is upturned in most caimanines, including Mourasuchus species (see Brochu, 1997, 1999; Cidade et al., 2017).

Both UFAC-1424 and LACM-160157 preserve the frontal, postorbital, parietal, squamosals, quadrates, quadratojugals, jugals, exoccipitals, pterygoids, ectopterygoids, laterosphenoids, and palatines.

The frontal is incomplete in both specimens. In UFAC-1424 the frontal lacks most of the lateral portions, except for the posterior-most parts, in which the bone is elevated (Figure 8) as in all Mourasuchus and most caimanines except Culebrasuchus, Globidentosuchus, Gnatusuchus and Kuttanacaiman (Souza-Filho et al., 2019). In LACM-160157, most of the anterior portion of the frontal is absent, although the preserved lateral portions of the bone demonstrate that the medial
FIGURE 9. Skull of UFAC-1424 (Mourasuchus cf. M. amazonensis) in occipital view with schematic drawing. Abbreviations: ex, exoccipital; ptf, postemporal fenestra; q, quadrate; qj, quadratojugal; so, supraoccipital; sq, squamosal. Scale equals $10 \mathrm{~cm}$.

margins of the orbits are upturned (Figure 14). The interorbital bar is broad, as in all Mourasuchus specimens (see Langston, 1965; Bocquentin-Villanueva, 1984; Scheyer et al., 2013; Scheyer and Delfino, 2016; Cidade et al., 2017; Figures 8 and 14). The frontal of UFAC-1424 is short, likely not reaching the anterior portion of the orbits, as seen in several caimanines such as Mourasuchus atopus, Purussaurus neivensis, P. mirandai, Gnatusuchus, Globidentosuchus, Kuttanacaiman, and Caiman wannlangstoni. The frontal contacts the postorbitals, posterolaterally, and the parietal, posteriorly (Figures 8 and 14). The frontoparietal suture is linear in UFAC-1424 (Figure 8) but is anteriorly concave in LACM-160157 (Figure 14). This variation is also seen in extant caimanine species (G. Cidade, personal observation).

The postorbitals form the anterolateral corners of the skull table in both specimens, as it is common in Crocodylia (see lordansky, 1973; Figures 8 and 14). The descending processes of the postorbital are not preserved in UFAC-1424 and have only their dorsal-most parts preserved in LACM-160157. As such, it is not possible to confirm whether the postorbitals contacted the quadrate, the quadratojugal, or both, in the dorsal corner of the infratemporal fenestrae (Brochu, 2011, Character 143). The postorbitals contact the 


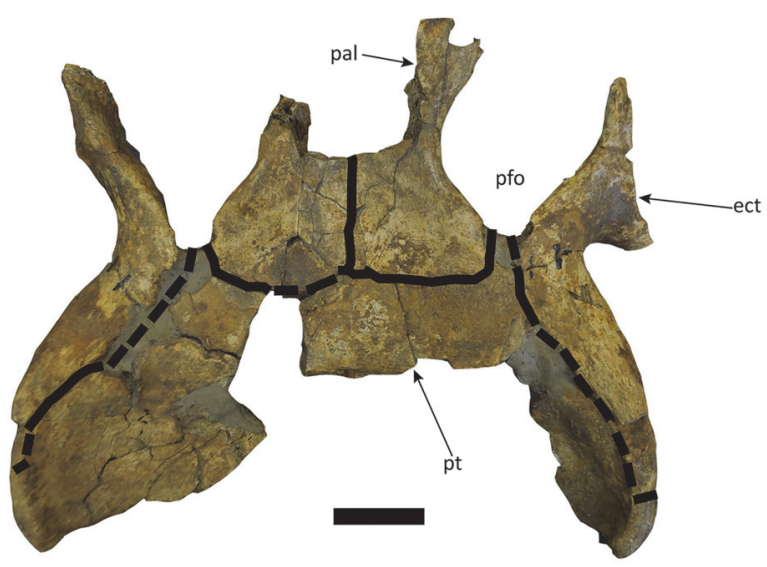

FIGURE 10. Posterior portion of the palate of UFAC-1424 (Mourasuchus cf. M. amazonensis) in ventral view. Abbreviations: ect, ectopterygoid; pal, palatine; pfo, palatine fossa; pt, pterygoid. Scale equals 5 $\mathrm{cm}$.

partietal laterally, the squamosals posteriorly, and form the anterolateral borders of the supratemporal fenestrae.

The parietal is roughly pentagonal in shape in both specimens (Figures 8 and 14). The parietal median crest, which is well-developed in all Mourasuchus specimens (see Gasparini, 1985; Bona et al., 2013a and 2013b; Scheyer and Delfino, 2016; Cidade et al., 2018), is not preserved in UFAC-1424 (although an eroded area in the medial portion of the parietal may represent the location where the parietal crest was situated before being fragmented) and is preserved only in its most posterior portion in LACM-160157. The parietal forms the medial part of the supratemporal fenestrae and contacts the squamosals, posterolaterally, and the supraoccipital, posteriorly (Figures 8 and 14). The supratemporal fenestrae of both specimens are small with the entirety of their margins overhung by the dermal bones of the skull table (Figures 8 and 14), as in most caimanines except Culebrasuchus and Purussaurus (see Hastings et al., 2013; Cidade et al., 2017). The fenestrae of the two specimens are tri-lobed in shape (Figure 8 and 14), although the right fenestra of UFAC-1424 is eroded along its lateral and anterolateral margins (Figure 8). Variation in the shape of the supratemporal fenestrae between circular and tri-lobed has been observed among Mourasuchus specimens by Bona et al. (2013b).

The squamosal is nearly completely preserved in both specimens. They exhibit the squamosal eminences ("horns") that have been observed in all Mourasuchus specimens that pre- serve the squamosal (see Gasparini, 1985; Bocquentin and Souza-Filho, 1990; Bona et al., 2013a and 2013b; Scheyer and Delfino, 2016; Cidade et al., 2017, 2018; Figures 8, 9, 13, 14 and 15). This feature is well-developed in both specimens. In dorsal view, the squamosals contact the supraoccipital laterally and form the posterolateral margin of the supratemporal fenestrae (Figures 8 and 14). In occipital view, the squamosals contact the supraoccipital medially and the exoccipital ventrally. The squamosals also form the lateral margins of the postemporal fenestrae in both specimens in addition to forming nearly half of the dorsal margin of the fenestrae in UFAC-1424 and nearly all of the dorsal margin of the fenestrae in LACM-160157 (Figures 9 and 15). This variation had not been observed in previous works. In lateral view, the squamosals contact the quadrates ventrolaterally and constitute most of the posterior border of the otic opening of the tympanic cavity (Figure 13), except in the right side of UFAC-1424, in which the otic opening is preserved only in its most dorsal portion.

The supraoccipital is completely preserved in both dorsal and occipital views in both specimens (Figures 8, 9, 14, and 15). In dorsal view, the supraoccipital is well-exposed within the skull table, excluding the parietal from the posterior margin of the skull table (Figures 8 and 14) as is seen in most caimanines except Purussaurus neivensis, P. mirandai, Paleosuchus, and Tsoabichi (see Langston, 1965; Aguilera et al., 2006; Brochu, 2010; Cidade et al., 2017; Souza-Filho et al., 2019). In these two specimens, the supraoccipital is highly elevated in occipital view (Figures 9 and 15), albeit not as much as the squamosals; in another Mourasuchus specimen, AMNH-14441 (see Cidade et al., 2019b), the supraoccipital is as elevated as the squamosals in the posterior portion of the skull table. This difference is potentially explicable via ontogenetic variation (see Cidade et al., 2019b). In occipital view, the supraoccipital bears a median crest, which is significantly larger in UFAC-1424 than in LACM-160157. This crest has been proposed to serve as attachment area for cervical muscles in Mourasuchus (Bona et al., $2013 b)$. Also in occipital view, the supraoccipital contacts the exoccipitals ventrally and ventrolaterally and forms the medial margin, the medial-most portions of the dorsal margin, and the medial portion of the ventral margin of the postemporal fenestrae (Figures 9 and 15). These fenestrae are large and represent the openings for the orbitotemporal canals, which are anteroposteriorly deep in both 
1

2
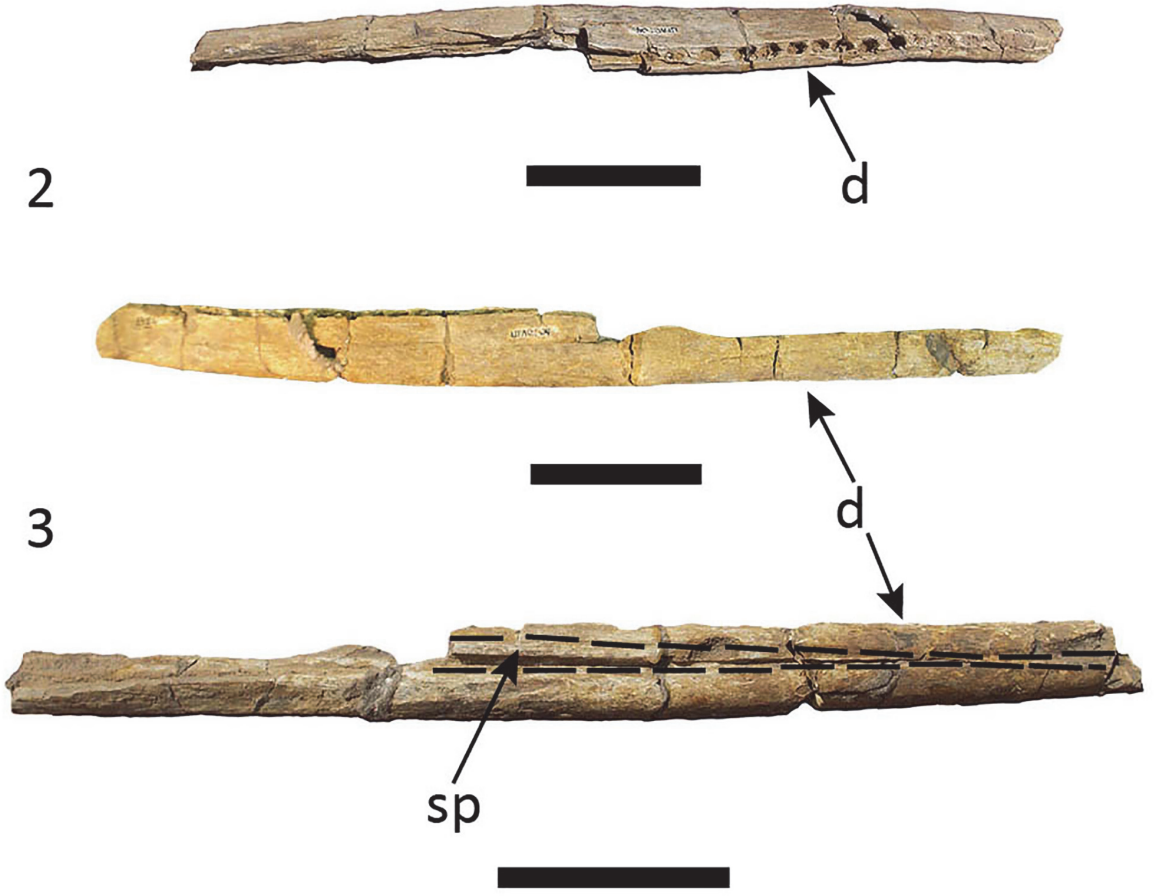

FIGURE 11. Left mandibular ramus of UFAC-1424 (Mourasuchus cf. M. amazonensis) in dorsal (1), lateral (2) and medial views (3). Abbreviations: d, dentary; sp, splenial. Scale equals $10 \mathrm{~cm}$.

specimens. The large size of both the postemporal fenestrae and the orbitotemporal canals is a morphology shared with other Mourasuchus specimens (see Bona et al., 2013b; Cidade et al., 2019b).

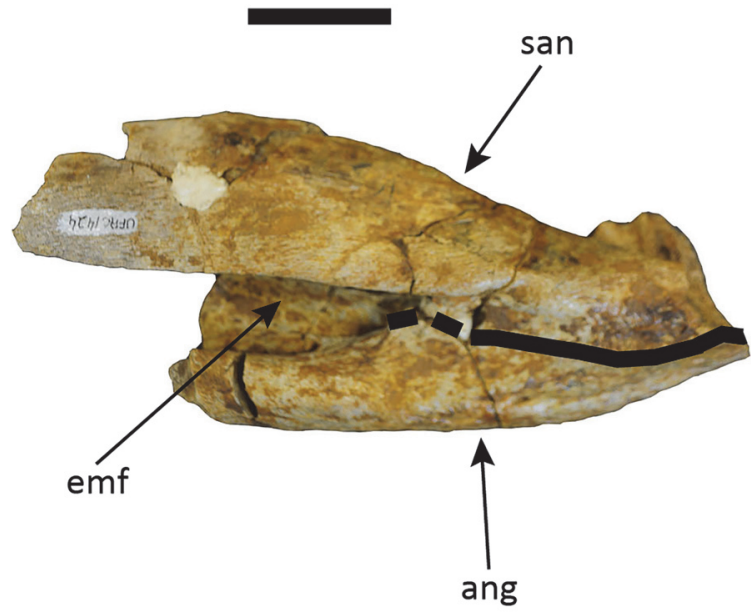

FIGURE 12. Posterior portion of the left mandible of UFAC-1424 (Mourasuchus cf. M. amazonensis) in lateral view. Abbreviations: ang, angular; emf, external mandibular fenestra; san, surangular. Scale equals $5 \mathrm{~cm}$.
Both quadrates are nearly completely preserved in both specimens. The lateral hemicondyles are eroded in UFAC-1424 (Figure 9) but are nearly completely preserved in LACM-160157 (Figure 15). As in all alligatoroids, they are larger than the medial hemicondyles (Brochu, 2011; Character 181-1), (Souza-Filho et al., 2019). The foramen

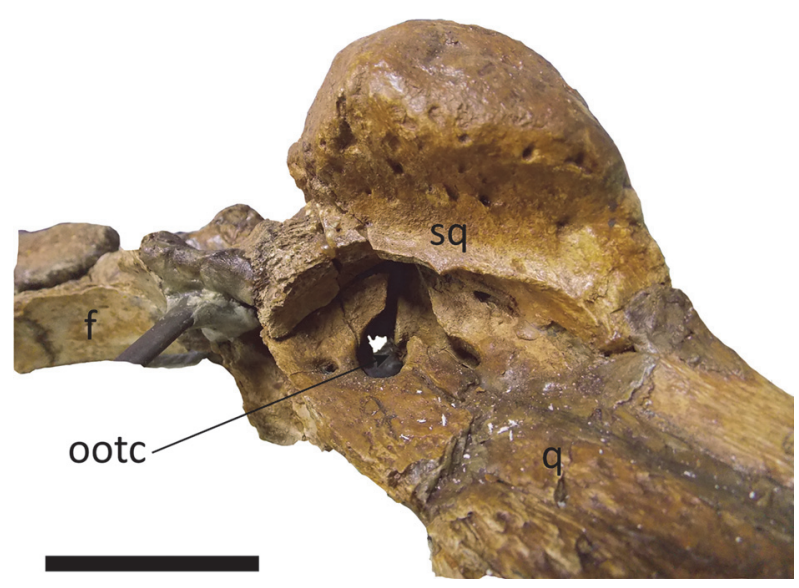

FIGURE 13. Skull table of UFAC-1424 in left lateral view. Abbreviations:; $f$, frontal; ootc, otic opening of the tympanic cavity; q, quadrate; sq, squamosal. Scale equals 5 $\mathrm{cm}$. 

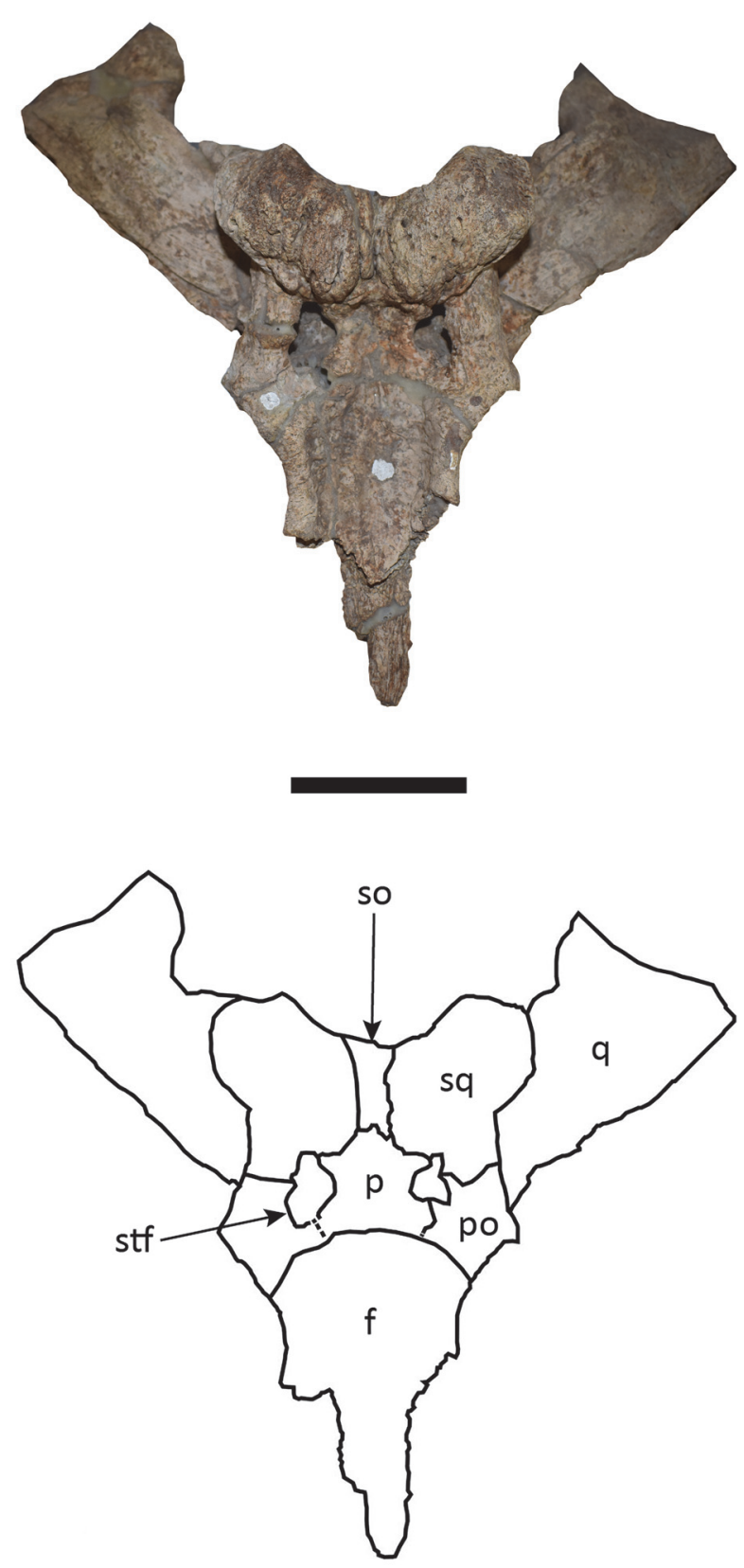

FIGURE 14. Posterior portion of the skull of LACM160157 (Mourasuchus cf. M. amazonensis) in dorsal view with schematic drawing. Abbreviations: $f$, frontal; $p$, parietal; po, postorbital; q, quadrate; so, supraoccipital; sq, squamosal; stf, supratemporal fenestra. Scale equals $10 \mathrm{~cm}$.

aereum is located within a notch on the dorsal surface of the quadrate (Brochu, 2011; Character 1811), a morphology observed in most alligatoroids (Brochu, 2011) (Brochu, 2011; Character 177-1) (Cidade et al., 2017; Souza-Filho et al., 2019). In ventral view, the crest $A$ of the quadrate (sensu lordansky, 1973) can be seen in the quadrates of both specimens. The quadrates contact the quadratoju- gals medially and posteromedially, the exoccipitals medially (Figures 9 and 15), and the squamosals dorsally (Figure 13). In lateral view, the quadrates also comprise the anterior and ventral margins of the otic openings of the tympanic cavities (Figure 13), except in the right side of UFAC-1424 in which the opening is preserved only in its most dorsal portion.

Only the posterior portions of the quadratojugals are preserved in LACM-160157, and these are not articulated with either the quadrates or the jugals (Figure 16). In UFAC-1424, however, the quadratojugals are almost completely preserved and articulated with the quadrates medially and with the jugals anterolaterally (Figures 8 and 9). In this specimen, the quadratojugals extend processes medially to the jugal and anteriorly to the quadrates (Figure 8). However, it is not possible to state whether the quadratojugal reached the dorsal angle of the infratemporal fenestrae as the medialmost portions of the medial processes of the quadratojugals are not preserved in UFAC-1424. In LACM-160157, the anterolateral margins of the quadrates preserve the sutures with the quadratojugals throughout most of the margin, but the sutures are not evident in the most dorsal portion of the quadrate. As such, it is also not possible to state whether the quadratojugal reached the dorsal angle of the infratemporal fenestrae in LACM160157. In UFAC-1424, the quadratojugal comprises all of the posterior border of the infratemporal fenestrae (Figure 8).

With the exception of their eroded anterior portions, the jugals are nearly completely preserved in both specimens (Figure 8). The jugals of UFAC-1424 are articulated with other remains of the skull (Figure 8), whereas those of LACM160157 are isolated (Figure 17). The subtemporal rami of the jugals of both specimens are lateromedially wide and dorsoventrally flattened (Figures 8 and 17), the same as the morphology seen in the holotype of Mourasuchus amazonensis (see above). This is an autapomorphy of the species and one of the characters that allows for the assignment of UFAC-1424 and LACM-160157 to Mourasuchus cf. amazonensis (see below).

The exoccipitals are nearly completely preserved in LACM-160157 (Figure 15), whereas the most ventral portions of these bones are eroded in UFAC-1424, especially in the left bone (Figure 9). The two exoccipitals meet medially, preventing the supraoccipital from reaching the foramen magnum (Figures 9 and 15). Their surfaces are smooth, without the presence of a boss in the paraoccipital 


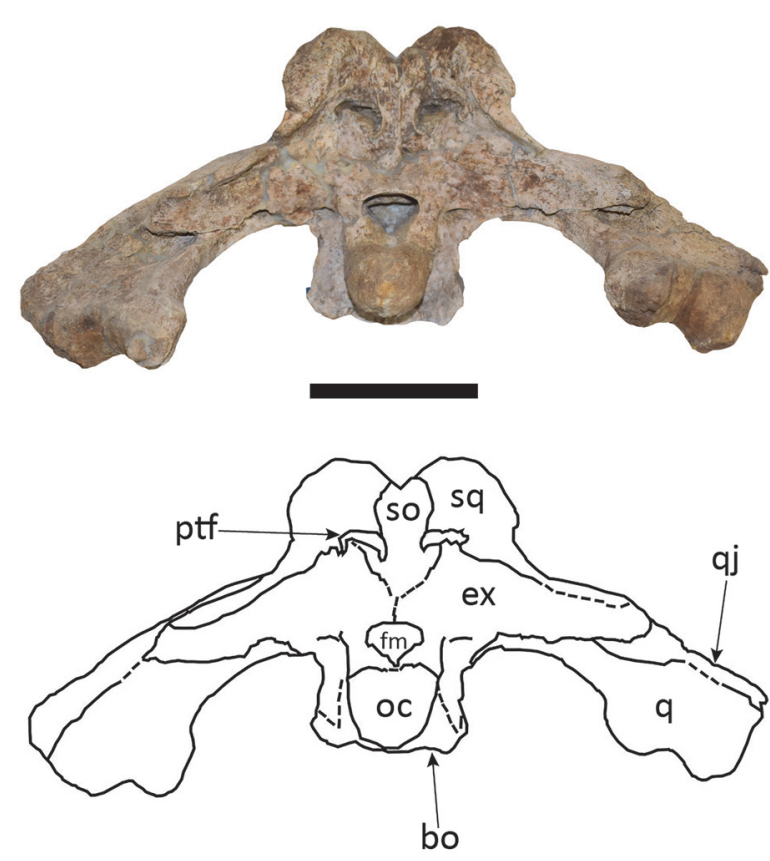

FIGURE 15. Posterior portion of the skull of LACM160157 (Mourasuchus cf. M. amazonensis) in occipital view with schematic drawing. Abbreviations: bo, basioccipital; ex, exoccipital; fm, foramen magnum; oc, occipital condyle; ptf, postemporal fenestra; q, quadrate; qj, quadratojugal; so, supraoccipital; sq, squamosal. Scale equals $10 \mathrm{~cm}$.

processes, a common morphology in crocodylian taxa (lordansky, 1973; Brochu, 2011; Souza-Filho et al., 2019). These bones form the lateral portion of the ventral margin of the postemporal fenestrae. In LACM-160157 each exoccipital sends slender ventral processes lateral to the basioccipital, but these do not comprise the basioccipital tubera (Brochu, 2011; Character 176-2; Figure 15), as in most caimanines except Culebrasuchus (see Brochu, 2011; Hastings et al., 2013; Cidade et al. 2017; Souza-Filho et al., 2019).

1

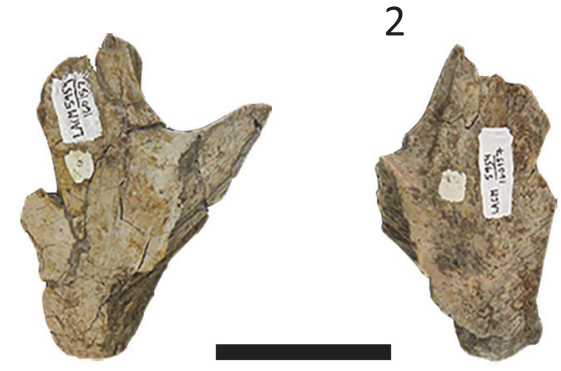

FIGURE 16. Left (1) and right (2) quadratojugals of LACM-160157 (Mourasuchus cf. M. amazonensis) in dorsal view. Scale equals $5 \mathrm{~cm}$.
The basioccipital is preserved only in LACM160157 (Figure 15). The bone forms the occipital condyle dorsally (Figure 15), and the basioccipital plate and the basioccipital tubera ventrally, as in most non-gavialoid crocodylians (see Brochu, 1997). The basioccipital plate exhibits a median crest, which in crocodylians serves as the attaching surface for the tendons of the $m$. occipitotransversalis profundus and $m$. basioccipitalvertebralis (lordansky, 1973; Bona et al., 2013b). The basioccipital forms the posterior margin of the ventral portions of the Eustachian canals (the medial canal as well as the lateral ones) and anteriorly contacts the basisphenoid (also only preserved in LACM160157), which comprises the anterior margin of the same structures. The basisphenoid is also exposed in the anterior area of the braincase of LACM-160157, although the basisphenoid rostrum is only preserved in its most posterior portion.

Both specimens preserve parts of the pterygoids, mostly comprised of the ventral portions of the bones (Figures 10 and 18). Although abraded, LACM-160157 preserves most of the ventral portions of the pterygoids, except for the medial-most portions of the anteriormost and posteriormost parts (Figure 18). Due to erosion in the posteriormost region, the exit of the secondary choana is not preserved in LACM-160157. The pterygoids of UFAC-1424 are more incomplete, missing most of the medial portions of both bones and the medial part of the anterior portion of the right pterygoid (Figure 10). The secondary choana is also not preserved in this specimen. In both specimens, however, it is possible to observe that the pterygoids contact the ectopterygoids, laterally and anterolaterally, whereas in UFAC-1424 it is possible to observe the pterygoids contacting the palatines anteriorly (Figures 10 and 18). LACM-160157 also preserves part of the most dorsal portions of the pterygoids, which form part of the lateral walls of the braincase via contact with the basisphenoid anteromedially, the quadrates posterolaterally and the laterosphenoids dorsally, as is similarly described for other specimens of Mourasuchus by Bona et al. (2013b). These dorsal portions of the pterygoids are not preserved in UFAC-1424.

The two ectopterygoids of both specimens are present and articulated with the pterygoids (Figures 10 and 18). Those of UFAC-1424 are nearly completely preserved (Figure 10), whereas the left ectopterygoid of LACM-160157 has its anterior and lateral portions eroded, and the right ectopterygoid of the same specimen has both the anterior and the posterior portions eroded (Figure 18). The 

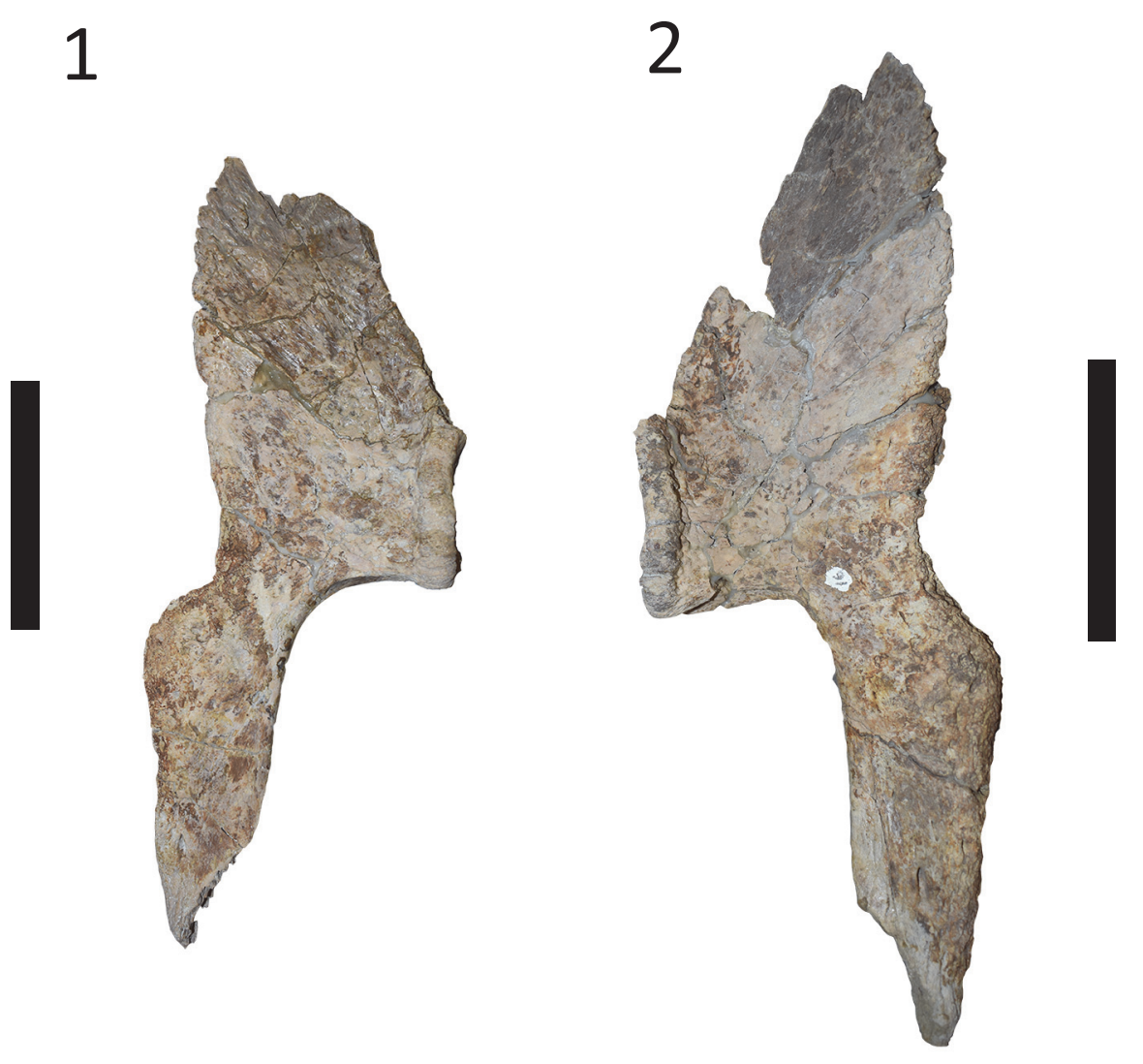

FIGURE 17. Left (1) and right (2) jugals of LACM-160157 (Mourasuchus cf. M. amazonensis) in dorsal view. Scale equals $10 \mathrm{~cm}$.

ectopterygoids preserve the anterior and the posterior ("pterygoid") processes and comprise the posterolateral margin of the suborbital fenestrae, as in most crocodylians (see Brochu, 1997). The morphology preserved in UFAC-1424 (Figure 10) suggests that the ectopterygoids did not meet the palatines in the posterior border of the suborbital fenestrae, thereby allowing the pterygoids to contact the fenestrae; this morphology is seen in most crocodylians except Caiman yacare (Brochu, 1997). However, this interpretation is stated tentatively because the posterior border of the suborbital fenestrae is filled with an epoxy material in UFAC-1424.

The posterior portions of both palatines and most of the lateral portion of the left palatine are preserved and articulated posteriorly with the pterygoids in UFAC-1424 (Figure 10). LACM-160157 preserves an almost complete right palatine and a left palatine that lacks most of its anteromedial portion and part of its anterolateral portion (Figure 19). The palatines of both specimens are lateromedially wide, as in the holotypes of $M$. amazonensis (see above) and $M$. arendsi, but distinct from the holo- types of $M$. atopus and $M$. pattersoni (see Langston, 1965; Bocquentin-Villanueva, 1984; Bocquentin and Souza-Filho, 1990; Scheyer and Delfino, 2016; Cidade et al., 2017). This is one of the features that allows assignment of these specimens to Mourasuchus cf. amazonensis (see below).

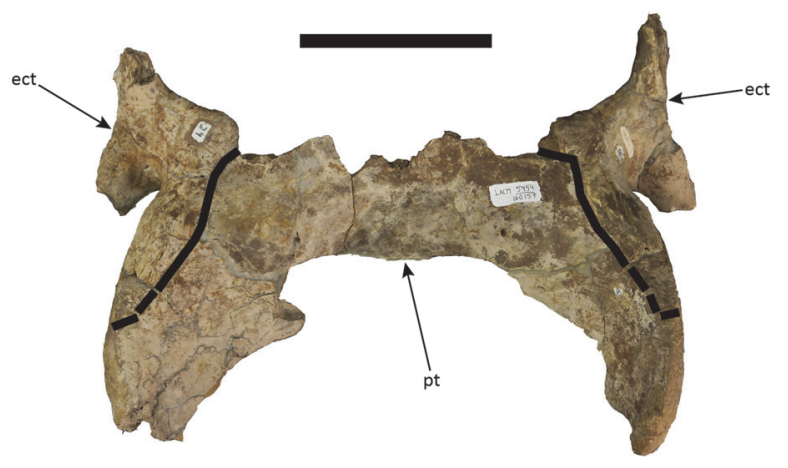

FIGURE 18. Posterior portion of the palate (pterygoid and ectopterygoids) of LACM-160157 (Mourasuchus cf. M. amazonensis) in ventral view. Abbreviations: ect, ectopterygoid; pt, pterygoid. Scale equals $10 \mathrm{~cm}$. 
Both laterosphenoids are preserved in LACM160157 (Figure 20), exhibiting the caudal and the lateral bridges, the capitate processes, and the opening of the trigeminal fossa (trigeminal foramen). The laterocaudal bridge (sensu Bona et al., 2011; see Bona et al., 2013a) is not completely preserved in LACM-160157, but the dorsal portions of the bridge can be seen in the medial area of the dorsal margin of the trigeminal foramen, especially in the left laterosphenoid, evidencing the presence of the structure in this specimen. Most of the anterior surface of the braincase is absent in UFAC1424 , with only an eroded remnant of the dorsalmost portion visible. As such, it is possible that parts of the capitate processes are preserved, but other structures of these bones are absent.

LACM-160157 also has three very fragmentary remains that possibly come from the rostrum (Figure 21). One of them (Figure 21.1) may represent part of one of the maxillae or parts of the prefrontal or the lacrimal, whereas the other two are too fragmentary to allow any identification.

UFAC-1424 preserves a fragmentary left mandible comprised of the dentary with small parts of the splenial (Figure 11) and the posterior portion of a left mandible (Figure 12). The anterior portion of

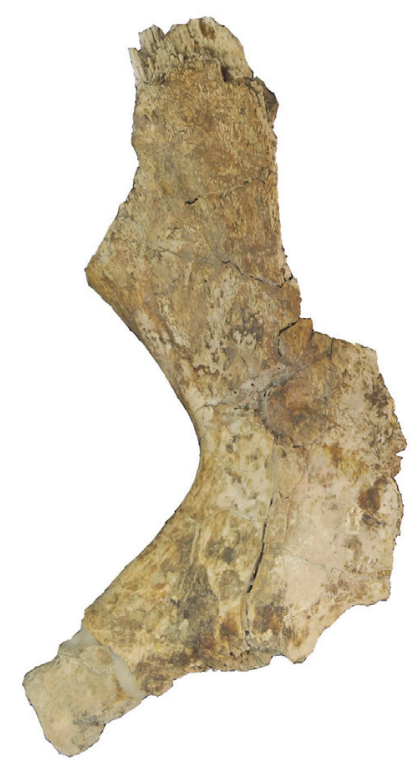

the dentary, including the symphysis, is absent. The ventral portion of the dentary fragment is more complete than the dorsal one, which includes the tooth row (Figure 11), and may be preserved through to the posterior end of the dentary. The tooth row preserves 18 alveoli, which are roughly equal in size. Given that the first four or five alveoli are significantly large than the posterior ones in Mourasuchus (see Salas-Gismondi et al., 2015, and above), this fragment almost certainly represents a medial portion of the dentary. In medial view, part of the splenial and a groove that corresponds to the Meckelian canal, where the rest of the splenial would articulate with the dentary, can be seen (Figure 11.3). In the most anterior portion of the fragment, part of the canal is closed by a small remnant of the medial portion of the left splenial (Figure 11.3), but no other parts of the medial portion of this bone are preserved.

The posterior portion of the left mandible comprises incomplete parts of the posterior portions of the surangular and angular (Figure 12) and an incomplete anteroventral portion of the articular, all of which are articulated. In lateral view, the angular-surangular suture probably contacts the external mandibular fenestra at the posterior angle

\section{2}

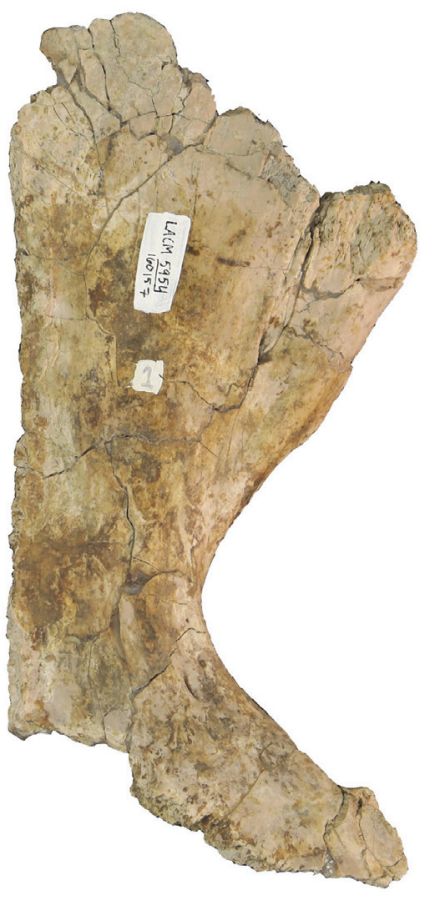

FIGURE 19. Right (1) and left (2) palatines of LACM-160157 (Mourasuchus cf. M. amazonensis) in ventral view. Scale equals $10 \mathrm{~cm}$. 
1

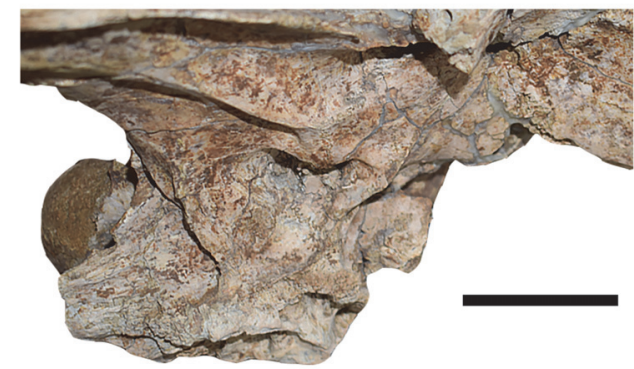

2

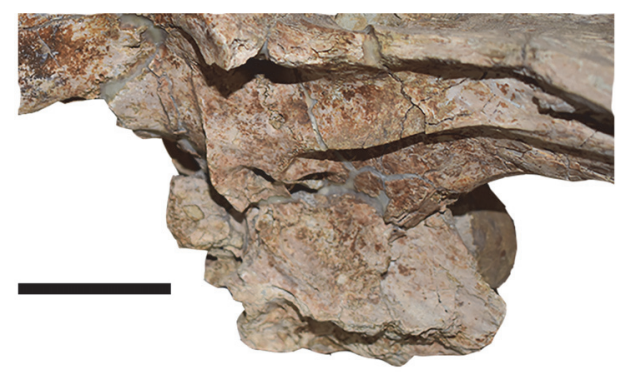

FIGURE 20. Anterolateral portions of the braincase of LACM-160157 in right (1) and left (2) views. Scale equals $5 \mathrm{~cm}$.

(Brochu, 2011, Character 60-0; Figure 12), as in most alligatoroids (Cidade et al., 2017), but deterioration in the anterior portion of the suture leaves some doubt about this. In dorsal view, the articular flushes against the surangular, and there is no sulcus between the two bones (Brochu, 2011, Character 74-1), as in most non-gavialoid crocodylians (Brochu, 1997, 2011).

\section{DISCUSSION}

The current impossibility of reassessing the dorsal region of the skull of the holotype precludes framing a formal diagnostic statement with regards to the taxonomic status of Mourasuchus nativus and of the two specimens here described (LACM160157 and UFAC-1424).

Mourasuchus nativus (Gasparini, 1985) was considered a junior synonym of $M$. arendsi by Scheyer and Delfino (2016) as its holotype (an isolated skull table from the late Miocene outcrops of the "Conglomerado osífero", Ituzaingó Formation, Argentina) is not distinct from the holotype of $M$. arendsi, mainly due to the fact that both exhibit squamosal eminences ("horns") and an elevated median crest in the parietal bone. The squamosals and the parietal are not preserved in the holotype of M. atopus (Langston, 1965) and were covered
1

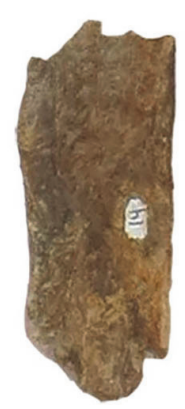

2

3
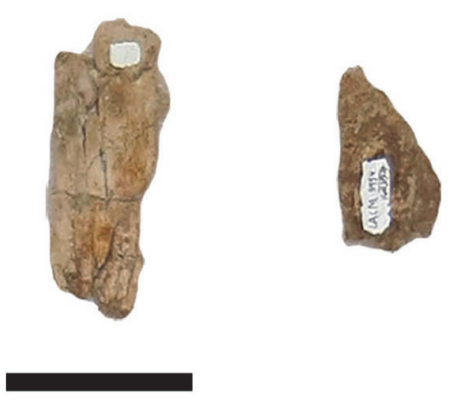

FIGURE 21. Three tentative rostral fragments of LACM160157 (Mourasuchus cf. M. amazonensis). Scale equals $5 \mathrm{~cm}$.

by plaster in the holotype of $M$. pattersoni (Cidade et al., 2017); in the holotype of $M$. amazonensis, however, the squamosal and the parietal may theoretically be reexamined. This cannot be currently done due to the attachment of the dorsal surface to a plaster jacket. An eventual confirmation of the presence of the squamosal horns and of the parietal median crest in the holotype of $M$. amazonensis (DGM 526-R) would make it indistinguishable from that of $M$. nativus, thus rendering the latter species a nomen dubium and not only the junior synonym of $M$. arendsi (see Cidade et al., 2018).

UFAC-1424 and LACM-160157 share with the holotype of Mourasuchus amazonensis a jugal bone in which the subtemporal ramus is lateromedially wide and dorsoventrally flattened. Additionally, we tentatively interpreted UFAC-1424 and LACM-160157 as sharing with the holotype lateromedially expanded palatines (although these bones are severely incomplete in the holotype, so this must be stated with caution), whereas the other diagnostic characters of $M$. amazonensis (external naris wider than long and tri-lobed incisive foramen) are not preserved in either of the specimens.

UFAC-1424 and LACM-160157 also exhibit squamosal eminences, while the latter specimen preserves part of the parietal median crest and the former exhibits an eroded area on the parietal that may represent a remnant of this crest. As such, while both specimens clearly have affinities with $M$. amazonensis, uncertainties regarding the dorsal morphology of the holotypic skull (DGM 526-R) in dorsal view (especially pertaining to the presence of the squamosal eminences and the parietal median crest) precludes a definitive assignment of these specimens to $M$. amazonensis, hence their 
TABLE 1. The status of the relevant taxonomic characters (column) in Mourasuchus in each of the species of the genus (row).

\begin{tabular}{lllll}
\hline \multicolumn{1}{c}{ Characters/Species } & M. amazonensis & M. arendsi & M. atopus & M. pattersoni \\
\hline Size of the external naris & Wider than long & Circular & Circular & Wider than long \\
Shape of the incisive foramen & Tri-lobed & Reversed tear-drop? & Not preserved & Circular \\
Lateromedial shape of the palatines & Wide? & Wide? & Constricted & Constricted \\
Shape of the jugals (lateromedially/dorsoventrally) & Wide/Flattened & Slender/Low & Slender/Low & Wide/High \\
Squamosal eminences & $?$ & Present & Not preserved & Not preserved \\
\hline
\end{tabular}

assignment as Mourasuchus cf. amazonensis in this paper.

The presence of squamosal eminences and the parietal median crest in the holotype of Mourasuchus amazonensis is here considered probable, since these two structures are seen in all Mourasuchus specimens that preserve the squamosal and the parietal (see Gasparini, 1985; Bocquentin and Souza-Filho, 1990; Bona et al., 2013a and 2013b; Scheyer and Delfino, 2016; Cidade et al., 2017, 2018, 2019b). The original drawing of the holotypic skull of $M$. amazonensis does not clearly depict the presence of hypertrophy in the squamosals. However, Price (1964) states that the skull table exhibits an "osseous excess" that "almost obliterates" the supratemporal fenestrae. Such description matches the squamosal hypertrophy observed in the other Mourasuchus specimens, and in one Mourasuchus specimen in which the squamosal hypertrophies are particularly large (AMNH-14441), the supratemporal fenestrae are obliterated (Cidade et al., 2019b). However, this description may also be related to the elevation of the bones surrounding the supratemporal fenestrae (see Brochu, 2011, Character 152), which is present in most caimanines, including Mourasuchus (Brochu, 2011; Cidade et al., 2017, 2019b). These observations notwithstanding, only an eventual direct reexamination of the dorsal morphology of the skull of the holotype can provide definitive evidence as to the presence or absence of these structures, as well as answering the attendant taxonomic questions that are dependent on this evidence.

Despite the taxonomic issues surrounding Mourasuchus nativus, LACM-160157 and UFAC1424, M. amazonensis can nonetheless be confidently distinguished from the species $M$. atopus, M. arendsi, and M. pattersoni (see Table 1 and Emended Diagnosis above). This observation preserves the status of $M$. amazonensis as a valid species despite any taxonomic reviews pertaining to $M$. nativus or LACM-160157 and UFAC-1424. Moreover, the genus Mourasuchus is one of the most distinct and recognizable taxa within crocodylian alligatoroids, being consistently recovered as a monophyletic group (Bona et al., 2013a, 2018; Salas-Gismondi et al., 2015; Cidade et al., 2017, 2018) and supported by a large number of unique characters (Cidade et al., 2017).

The eventual examination of the complete morphology of the holotypic skull of $M$. amazonensis and the possible eventual assignment of LACM-160157 and UFAC-1424 to the species may contribute significant new information to cladistic datasets that include the taxon, which are currently only represented by the holotype (Cidade et al., 2017). The only phylogenetic analyses published to date to include all valid Mourasuchus species (Cidade et al., 2017, 2018) found M. amazonensis to be closely related to $M$. pattersoni, whereas $M$. atopus and $M$. arendsi form another clade within the genus. The clade formed by $M$. amazonensis and $M$. pattersoni is supported by a single shared character: an external naris that is wider than long (see Cidade et al., 2017, Character 83, which is modified from Brochu, 2011, Character 83). However, a thorough reanalysis of the complete preserved morphology of the skull of $M$. amazonensis may force a reassessment of this scenario, in addition to further contributing to our general understanding of the phylogenetic relationships between the Mourasuchus species and between the genus and other caimanine alligatoroids.

\section{ACKNOWLEDGMENTS}

The first author thanks the following people for access to collections under their care: S. MacLeod and V. Rhue (LACM), R. Machado (MCT), G. Oneda (CIAAP), C. Mehling (AMNH) and A. Maciente (UFAC). H. de Paula Silva and his staff (MN-UFRJ) are deeply thanked for restoring the holotype of Mourasuchus amazonensis. R. Souza, A. Kellner, L. Carvalho, R. Veronese (MN-UFRJ), R. Machado (MCT), and D. Campos (MCT) are much thanked for helping in the restoration process. D. Campos (MCT) is also thanked for infor- 
mation about the holotype and for allowing the restoration of the specimen. We thank V. Rhue (LACM) for information about and pictures of LACM-160157 and K. Campbell (LACM) for information about the same specimen. P.R. Lopes (Universidade de São Paulo) is thanked for kindly sharing Figure 1 with us. We are very grateful to $B$. McPhee (University of São Paulo, Brazil) for a language review and suggestions that greatly improved the paper. We thank the editors D. Hembree, P. Getty, and three anonymous reviewers for suggestions and corrections that significantly improved the manuscript. This paper was funded by Fundação de Amparo à Pesquisa do Estado de
São Paulo (FAPESP) Master's Degree scolarship 2013/04516-1, Conselho de Desenvolvimento Científico e Tecnológico (CNPq) Doctorade scholarship 140808/2016-7 and Coordenação de Aperfeiçoamento de Pessoal de Nível Superior (CAPES) "Programa de Doutorado Sanduíche no Exterior - PDSE" grant 88881.131923/2016-01 and partial Doctorade scholarship (Finance Code 001) to GMC, FAPESP research grant 2011/ 14080-0 and CNPq research grant 309434/2015-7 to $\mathrm{ASH}$ and Fundação de Amparo à Pesquisa do Estado de Minas Gerais (FAPEMIG) grant APQ00581-09 to DR supported this research.

\section{REFERENCES}

Aguilera, O.A. 2004. Tesoros Paleontológicos de Venezuela: Urumaco, Património Natural de la Humanidad. Universidad Nacional Experimental Francisco de Miranda, Editora Arte, Caracas.

Aguilera, O.A., Riff, D., and Bocquentin-Villanueva, J. 2006. A new giant Purussaurus (Crocodyliformes, Alligatoridae) from the upper Miocene Urumaco Formation, Venezuela. Journal of Systematic Palaeontology, 4(3):221-232. https://doi.org/10.1017/ S147720190600188X

Bartels, W.S. 1984. Osteology and systematic affinities of the horned alligator Ceratosuchus (Reptilia, Crocodilia). Journal of Paleontology, 58:1347-1353.

Benton, M.J. and Clark, J.M. 1988. Archosaur phylogeny and the relationships of the Crocodylia, p. 295-338. In Benton, M.J. (ed.), The Phylogeny and Classification of the Tetrapods. Vol. 1. Clarendon Press, Oxford.

Bocquetin, J. C. and Buffetaut, E. 1981. Hesperogavialis cruxenti n. gen., n. sp., nouveau gavialide (Crocodylia, Eusuchia) du Miocène Supériur (Huayquerien) d'Urumaco (Venezuela). Geobios, 14:415-419.

Bocquentin, J. and Souza-Filho, J.P. 1990. O crocodiliano sul-americano Carandaisuchus como sinonímia de Mourasuchus (Nettosuchidae). Revista Brasileira de Geociências, 20:230-233.

Bocquentin-Villanueva, J. 1984. Um nuevo Nettosuchidae (Crocodylia, Eusuchia) proveniente de la Formación Urumaco (Mioceno Superior), Venezuela. Ameghiniana, 21:3-8.

Bona, P. and Barrios, F. 2015. The Alligatoroidea of Argentina: an update of its fossil record. Publicación Electrónica de la Asociación Paleontológica Argentina, 15(1):143-158. https:// doi.org/10.5710/PEAPA.15.06.2015.103

Bona, P. and Desojo, J.B. 2011. Osteology and cranial musculature of Caiman latirostris (Crocodylia; Alligatoridae). Journal of Morphology, 272(7):780-795. https://doi.org/10.1002/ jmor.10894

Bona, P., Riff, D., and Gasparini Z. 2013a. Late Miocene crocodylians from Northeast Argentina: New approaches about the austral components of the Neogene South American crocodylian fauna. Earth and Environmental Science Transactions of the Royal Society of Edinburgh, 103:1-20. https://doi.org/10.1017/S175569101300042X

Bona, P., Degrange, F.J., and Fernández, M. 2011. Skull anatomy of the bizarre Crocodylian Mourasuchus nativus (Alligatoridae, Caimaninae). Ameghiniana, 48(4):R77.

Bona, P., Degrange, F.J., and Fernández, M.S. 2013b. Skull anatomy of the bizarre crocodilian Mourasuchus nativus (Alligatoridae, Caimaninae). The Anatomical Record, 296(2):227-239. https://doi.org/10.1002/ar.22625

Bona, P., Ezcurra, M.D., Barrios, F., and Fernandez-Blanco, M.V. 2018. A new Palaeocene crocodylian from southern Argentina sheds light on the early history of caimanines. Proceedings of the Royal Society B, 285:20180843. https://doi.org/10.1098/rspb.2018.0843 
Bona, P., Fernandez-Blanco, M.V., Scheyer, T.M., and Foth, C. 2017. Shedding light on the taxonomic diversity of the South American Miocene caimans: The status of Melanosuchus fisheri (Crocodylia, Alligatoroidea). Ameghiniana, 54:681-687. https://doi.org/10.5710/ AMGH.08.06.2017.3103

Brochu, C.A. 1997. Phylogenetic Systematics and Taxonomy of Crocodylia. Unpublished PhD thesis, University of Texas at Austin, Austin, Texas, USA.

Brochu, C.A. 1999. Phylogenetics, taxonomy, and historical biogeography of Alligatoroidea. Memoir of the Society of Vertebrate Paleontology, 6:9-100. https://doi.org/10.2307/3889340

Brochu, C.A. 2011. Phylogenetic relationships of Necrosuchus ionensis Simpson, 1937 and the early history of caimanines. Zoological Journal of the Linnean Society, 163:S228-S256. https://doi.org/10.1111/j.1096-3642.2011.00716.x

Brochu, C.A., Njau, J., Blumenschine, R.J., and Densmore, L.D. 2010. A new horned crocodile from the Plio-Pleistocene hominid sites at Olduvai Gorge, Tanzania. PloS One, 5(2):e9333. https://doi.org/10.1371/journal.pone.0009333

Brochu, C.A. and Rincon, A.D. 2004. A gavialoid crocodylian from the Lower Miocene of Venezuela. Special Papers in Palaeontology, 71:61-78.

Campbell, K. E., Frailey, C.D., and Romero-Pittman, L. 2006. The Pan-Amazonian Ucayali Peneplain, late sedimentation in Amazonia, and the birth of the modern Amazon River system. Palaeogeography, Palaeoclimatology, Palaeoecology, 239:166-219. https://doi.org/ 10.1016/j.palaeo.2006.01.020

Caputo, M., Rodrigues, V., and Vasconcelos, D. 1971. Litoestratigrafia da Bacia do Rio Amazonas. Petrobras-Renor, Rio de Janeiro.

Cidade, G.M., Fortier, D., and Hsiou, A.S. 2019a. The crocodylomorph fossil record of the Cenozoic of South America and its evolutionary history: A review. Journal of South American Earth Sciences, 90:392-411. https://doi.org/10.1016/j.jsames.2018.12.026

Cidade, G.M., Solórzano, A., Rincón, A.D., Riff, D., and Hsiou, A.S. 2017. A new Mourasuchus (Alligatoroidea, Caimaninae) from the late Miocene of Venezuela, the phylogeny of Caimaninae and considerations on the feeding habits of Mourasuchus. PeerJ, 5:e3056. https://doi.org/10.7717/peerj.3056

Cidade, G.M., Solórzano, A., Rincón, A.D., Riff, D., and Hsiou, A.S. 2018. Redescription of the holotype of the Miocene crocodilian Mourasuchus arendsi (Alligatoroidea, Caimaninae) and perspectives on the taxonomy of the species. Historical Biology, online first. https://doi.org/ 10.1080/08912963.2018.1528246

Cidade, G.M., Souza-Filho, J.P., Hsiou, A.S., Brochu, C.A., and Riff, D. 2019b. New specimens of Mourasuchus (Alligatoroidea, Caimaninae) from the Miocene of Brazil and Bolivia and their taxonomic and morphological implications. Alcheringa: An Australasian Journal of Palaeontology, 43:261-278. https://doi.org/10.1080/03115518.2019.1566495

Cozzuol, M. A. 2006. The Acre vertebrate fauna: age, diversity, and geography. Journal of South American Earth Sciences, 21:185-203. https://doi.org/10.1016/j.jsames.2006.03.005

Cuvier, G.L. 1807. Sur les differentes especes de crocodiles vivan set sur leur caracteres distinctifs. Annales du Museum d'Histoire Naturelle Paris, 10:8-66.

Eiras, J.F., Becker, C.R., Souza, E.M., Gonzaga, F.G., Silva, J.G.F., Daniel, L.M.F., Matsuda, N.S., and Feijó, F.J. 1994. Bacia do Solimões. Boletim de Geociências da Petrobras, Rio de Janeiro: CENPES 8(1):17-45.

Fortier, D.C., Souza-Filho, J.P., Guilherme, E., Maciente, A., and Schultz, C.L. 2014. A new specimen of Caiman brevirostris (Crocodylia, Alligatoridae) from the Late Miocene of Brazil. Journal of Vertebrate Paleontology, 34(4):820-834. https://doi.org/10.1080/ 02724634.2014 .838173

Gasparini, Z. 1985. Un Nuevo cocodrilo (Eusuchia) Cenozoico de América del Sur. Coletânea de Trabalhos Paleontológicos MME-DNPM, Série Geologia, 27:51-53.

Gmelin, J. 1789. Linnei Systema Naturae. G.E. Beer, Leipzig.

Gray, J.E. 1844. Catalogue of tortoises, crocodilians, and amphisbaenians in the collection of the British Museum. British Museum (Natural History), London.

Gürich, G. 1912. Gryposuchus jessei ein neues schmalschnauziges Krokodil aus den jüngeren Ablagerungen des obreren Amazonas-Geibetes. Mitteilungen aus dem MineralogischGeologischen Institut in Hamburg, 29:59-71.

Hastings, A.K., Bloch, J.I., Jaramillo, C.A., Rincon, A.F., and MacFadden, B.J. 2013. Systematics and biogeography of crocodylians from the Miocene of Panama. Journal of Vertebrate Paleontology, 33(2):239-263. https://doi.org/10.1080/02724634.2012.713814 
lordansky, N.N. 1973. The skull of the Crocodylia, p. 201-262. In Gans, C. and Parsons, T.S. (eds.), Biology of the Reptilia, Vol. 4. Academy Press, New York.

Kerber L., Bissaro-Júnior, M.C., Negri, F.R., Souza-Filho, J.P., Guilherme, E., and Hsiou, A.S. 2018. A new rodent (Caviomorpha: Dinomyidae) from the upper Miocene of southwestern Brazilian Amazonia. Historical Biology, 30(7):985-993. https://doi.org/10.1080/ 08912963.2017 .1327529

Langston, W., Jr. 1965. Fossil crocodilians from Colombia and the Cenozoic history of the Crocodilia in South America. University of California Publications in Geological Sciences, 52:1-168.

Langston, W., Jr. 1966. Mourasuchus Price, Nettosuchus Langston, and the family Nettosuchidae (Reptilia: Crocodilia). Copeia, 4:882-885.

Langston, W., Jr. 2008. Notes on a partial skeleton of Mourasuchus (Crocodylia, Nettosuchidae) from the Upper Miocene of Venezuela. Arquivos do Museu Nacional, 66:125-143.

Langston, W., Jr. and Gasparini, Z. 1997. Crocodilians, Gryposuchus, and the South Americans gavials, p. 82-115. In Kay, R.F., Madden, R.H., Ciffelli, R.L., and Flynn, J.J. (eds.), Vertebrate Paleontology in the Neotropics: The Miocene Fauna of La Venta, Colombia. Smithsonian Institution, Washington.

Latrubesse, E.M. 1992. El Cuaternario fluvial de La cuenca del Purus en el estado de Acre, Brasil. Unpublished PhD thesis, Universidad Nacional de San Luis- San Luis, San Luis, Argentina.

Latrubesse, E.M., Bocquentin, J., Santos, J.C.R., and Ramonell, C.G. 1997. Paleoenvironmental model for the late Cenozoic of southwestern Amazonia: Paleontology and geology. Acta Amazonica, 27(2):103-118.

Latrubesse, E.M., Cozzuol, M., Silva-Caminha, S.A.F., Rigsby, C.A., Absy, M.L., and Jaramillo, C. 2010. The Late Miocene paleogeography of the Amazon Basin and the evolution of the Amazon River system. Earth-Science Reviews, 99:99-124. https://doi.org/10.1016/ j.earscirev.2010.02.005

Latrubesse, E. and Rancy, A. 1998. The late Quaternary of the Upper Jurua River, southwestern Amazonia, Brazil: Geology and vertebrate paleontology. Quaternary of South America and Antartic Peninsula, 11:27-46.

Linares, O.J. 2004. Bioestratigrafía de la fauna de mamíferos de las formaciones Socorro, Urumaco y Codoré (Mioceno medio-Plioceno temprano) de la región de Urumaco, Falcón, Venezuela. Paleobiología Tropical, 1:1-26.

Lopes, P.R.M. 2016. Descrição de um Fóssil de Eira barbara (Carnivora, Mustelidae) do Pleistoceno Final (Bacia do Acre) e Morfologia Comparada do Sincrânio de E. barbara Recente: Implicações Paleobiogeográficas, Geográficas e Taxonômicas. Unpublished Master's degree Dissertation, Universidade de São Paulo- Ribeirão Preto, São Paulo, Brazil.

Moreno-Bernal, J.W., Head, J., and Jaramillo, C.A. 2016. Fossil crocodilians from the High Guajira Peninsula of Colombia: Neogene faunal change in northernmost South America. Journal of Vertebrate Paleontology, 36:3 e1110586. https://doi.org/10.1080/ 02724634.2016 .1110586

Negri, F. R. 2004. Os Tardigrada (Mammalia, Xenarthra) do Neógeno, Amazônia Sul-Ocidental, Brasil. Unpublished PhD Thesis, Pontifícia Universidade Católica do Rio Grande do SulPorto Alegre, Rio Grande do Sul, Brazil.

Norell, M.A. 1988. Cladistic Approaches to Paleobiology as Applied to the Phylogeny of Alligatorids. Unpublished PhD thesis, Yale University, New Haven, Connecticut, USA.

Norell, M.A., Clark, J.M., and Hutchison, J.H. 1994. The Late Cretaceous alligatoroid Brachychampsa montana (Crocodylia): new material and putative relationships. American Museum Novitates, 3116:1-26.

Paolillo, A. and Linares, O.J. 2007. Nuevos cocodrilos Sebecosuchia del Cenozoico sudamericano (Mesosuchia: Crocodylia). Paleobiologia Neotropical, 3:1-25.

Patterson, B. 1936. Caiman latirostris from the Pleistocene of Argentina, and a summary of South American Cenozoic Crocodilia. Herpetologica, 1:43-54.

Patterson, B. 1943. Remarks on South American fossil crocodiles. Copeia, 1943:123-124.

Prasad, G.V.R. and de Broin, F.L. 2002. Late Cretaceous crocodile remains from Naskal (India): Comparisons and biogeographic affinities. Annales de Paléontologie, 88:19-71. https:// doi.org/10.1016/S0753-3969(02)01036-4

Price, L. 1964. Sobre o crânio de um grande crocodilídeo extinto do Alto de Rio Juruá, Estado do Acre. Anais da Academia Brasileira de Ciências, 56:59-66. 
Ribeiro, A.M., Madden, R.H., Negri, F.R., Kerber, L., Hsiou, A.S., and Rodrigues, K.A. 2013. Mamíferos fósiles y biocronología en el suroeste de la Amazonia, Brasil. Asociación Paleontológica Argentina - Publicación Especial, 14:207-221.

Riff, D. and Aguilera, O. 2008. The world's largest gharials Gryposuchus: Description of G. croizati n. sp. (Crocodylia, Gavialidae) from the Upper Miocene Urumaco Formation, Venezuela. Palaeontologische Zeitschrift, 82:178-95.

Riff, D., Romano, P.S.R., Oliveira, G.R., and Aguilera, O.A. 2010. Neogene crocodile and turtle fauna in Northern South America, p. 259-280. In Hoorn, C. and Wesselingh, F. (eds.), Amazonia, Landscape and Species Evolution: A Look Into the Past. Wiley-Blackwell, London.

Rusconi, C. 1933. Observaciones críticas sobre reptiles Terciarios de Paraná (Familia Alligatoridae). Revista de la Universidad Nacional de Córdoba, 20:1-52.

Salas-Gismondi, R., Antoine, P.O., Baby, P., Brusset, S., Benammi, M., Espurt, N., De Franceschi, D., Pujos, F., Tejada, J., and Urbina, M. 2007. Middle Miocene crocodiles from the Fitzcarrald Arch, Amazonian Peru. Cuadernos del Museo Geominero, 8:355-360.

Salas-Gismondi, R., Flynn, J.J., Baby, P., Tejada-Lara, J.V., Wesselingh, F.P., and Antoine, P-O. 2015. A Miocene hyperdiverse crocodylian community reveals peculiar trophic dynamics in proto-Amazonian mega-wetlands. Proceedings of the Royal Society, 282:20142490. https:// doi.org/10.1098/rspb.2014.2490

Scheyer, T.M., Aguilera, O.A., Delfino, M., Fortier, D.C., Carlini, A.A., Sánchez, R., CarrilloBriceño, J.D., Quiroz, L., and Sánchez-Villagra, M.R. 2013. Crocodylian diversity peak and extinction in the late Cenozoic of the northern Neotropics. Nature Communications, 4:1907. https://doi.org/10.1038/ncomms2940

Scheyer, T.M. and Delfino, M. 2016. The late Miocene caimanine fauna (Crocodylia: Alligatoroidea) of the Urumaco Formation, Venezuela. Palaeontologia Electronica, 19.3.48A:1-57. https://doi.org/10.26879/657 https://palaeo-electronica.org/content/2016/1625-caimanines-from-urumaco-formation

Scheyer, T.M. and Moreno-Bernal, J.W. 2010. Fossil crocodylians from Venezuela in the context of South American faunas, p. 192-213. In Sánchez-Villagra, M.R., Aguilera, O.A., and Carlini, A.A (eds.), Urumaco and Venezuelan Palaeontology - The Fossil Record of the Northern Neotropics. Indiana University Press, Bloomington.

Simpson, G.G., and Paula-Couto, C. 1981. Fossil Mammal from the Cenozoic of Acre, Brazil III Pleistocene Edentata, Pilosa, Proboscidea, Sirenia, Perissodactyla and Artiodactyla. Iheringia, Série Geologia, 6:11-73.

Souza, R.G., Cidade, G.M., Campos, D.A., and Riff, D. 2016. New crocodylian remains from the Solimões Formation (Lower Eocene-Pliocene), state of Acre, southwestern Brazilian Amazonia. Revista Brasileira de Paleontologia, 19(2):217-232. https://doi.org/10.4072/ rbp.2016.2.06

Souza-Filho, J.P. 1993. Ocorrência de Charactosuchus fieldsi e Charactosuchus n. sp. (Crocodilia, Crocodilidae) no Neógeno da Amazônia brasileira. Ameghinana, 30(1):113.

Souza-Filho, J.P. and Guilherme, E. 2011a. Novo registro de Mourasuchus amazonensis Price, 1964, no Mioceno-Superior do Estado do Acre, Brasil. Anais do XXII Congresso Brasileiro de Paleontologia, Natal, 1:656-659.

Souza-Filho, J.P. and Guilherme, E. 2011b. Ampliacão da diagnose e primeiro registro de Mourasuchus arendsi (Crocodylia-Nettosuchidae) no Neógeno da Formacão Solimões, Amazônia Sul-Ocidental, p. 399-408. In Carvalho, I.S. (ed.), Paleontologia: Cenários de Vida. 1 Edition. Vol. 4. Interciência, Rio de Janeiro.

Souza-Filho, J.P., Souza, R.G., Hsiou, A.S., Riff, D., Guilherme, E., Negri, F.R., and Cidade, G.M. 2019. A new caimanine (Crocodylia, Alligatoroidea) species from the Solimões Formation of Brazil and the phylogeny of Caimaninae. Journal of Vertebrate Paleontology, online first. https://doi.org/10.1080/02724634.2018.1528450

Tineo, D.E., Bona, P., Pérez, L.M., Vergani, G.D., González, G., Poiré, D.G., Gasparini, Z.N., and Legarreta, P. 2014. Palaeoenvironmental implications of the giant crocodilian Mourasuchus (Alligatoridae, Caimaninae) in the Yecua Formation (late Miocene) of Bolivia. Alcheringa, 39(2):224-235. https://doi.org/10.1080/03115518.2015.967162 


\section{APPENDIX 1}

List of osteological specimens of extant caimanine species used for anatomical comparison

Caiman crocodilus: AMNH-R-43291, AMNH-R-73048, AMNH-R-137179, MCT-148-RR, MCT155-RR, MCT-300-RR, MN-67, MN-1030, MN-1031, MN-25188, MN-25461.

Caiman latirostris: AMNH-R-28367, AMNH-R-143183, MACN-30566, MACN-30567, MACN30572, MACN-30610, MACN-30612, MCT-156-RR, MCT-157-RR, MN-1041, MN-1254, MN1255, MN-1455, MN-2333, MN-9756, MN-11254, MN-24588.

Caiman yacare: AMNH-R-97305, MACN-30540, MACN-30542, MACN-30558, MACN-30593, MACN-30595, MACN-30601, MACN-30602, MACN-30637, MACN-I-8267, MN-68, MN-1259, MN-9755, MN-12127.

Melanosuchus niger: AMNH-R-58130, MCT-286-RR, MN-61, MN-63, MN-64, MN-66, MN-81, MN-3174.

Paleosuchus palpebrosus: AMNH-R-93812, AMNH-R-97326, MCT-269-RR, MCT-291-RR, MN317, MN-2356.

Paleosuchus trigonatus: AMNH-R-58136, AMNH-R-66391, MN-65, MN-2491, MN-9757. 